\title{
Bacterial diversity associated with mineral substrates and hot springs from caves and tunnels of the Naica Underground System (Chihuahua, Mexico)
}

\author{
Adriana Espino del Castillo ${ }^{1}$, Hugo Beraldi-Campesi ${ }^{3}$, Patricia Amador-Lemus ${ }^{2}$, \\ Hiram I. Beltrán ${ }^{4}$, and Sylvie Le Borgne ${ }^{2^{*}}$ \\ ${ }^{1}$ Doctorado en Ciencias Biológicas y de la Salud, Universidad Autónoma Metropolitana (Unidades Cuajimalpa, Iztapalapa y Xochimilco) \\ ${ }^{2}$ Departamento de Procesos y Tecnología, Universidad Autónoma Metropolitana-Cuajimalpa, Av. Vasco de Quiroga 4871, \\ Col. Santa Fe Cuajimalpa, 05300 Ciudad de México, Mexico \\ ${ }^{3}$ SOMA, Universidad Nacional Autónoma de México, Ciudad Universitaria, 04510 Ciudad de México, Mexico \\ ${ }^{4}$ Departamento de Ciencias Naturales, Universidad Autónoma Metropolitana-Cuajimalpa, Av. Vasco de Quiroga 4871, \\ Col. Santa Fe Cuajimalpa, 05300 Ciudad de México, Mexico
}

\begin{abstract}
The Naica Underground System (NUS) in Northern Mexico comprises a lead, zinc, and silver producing mine and displays the largest gypsum crystals ever found in natural caves. The caves are now closed to the public and mining activities have been suspended for an undefined period since October 2015. Besides its geological, economical, and tourist importance, the bacterial diversity in the NUS has not been fully explored yet. This study surveyed for bacteria present on different mineral substrates (gypsum crystals, iron oxide crusts) and hot spring samples collected before the NUS was inaccessible, using culture-dependent and culture-independent (PCR-DGGE) methods. This study is the first reporting the isolation of microorganisms from Naica. Cluster analysis of DGGE fingerprints revealed slight differences between communities from caves and tunnels and according to their mineral substrate type while communities from solid substrates and water samples appeared to be more distant. Both approaches, culture-dependent and independent, revealed the presence of bacteria from the Firmicutes, Alphaproteobacteria, Betaproteobacteria, and Gammaproteobacteria in gypsum crystals, iron oxide crusts, and hot springs, respectively. Deinococcus-Thermus and Actinobacteria were only detected by DGGE in hot spring samples. According to $16 \mathrm{~S}$ rRNA sequencing, heterotrophic bacteria isolated under aerobic conditions were affiliated with Bacillus, Brevibacillus, Paenibacillus, Schlegelella, Cupriavidus, Pseudoxanthomonas, and Lysobacter. Most of the isolates and sequences retrieved by DGGE were related to organisms previously detected in other extreme subsurface environments. Some of the isolates were able to precipitate calcium carbonate and precipitate $\mathrm{Fe}(\mathrm{III})$ in solid media but their possible participation in biomineralization processes in situ has still to be investigated. Microbial communities found in the NUS are likely autochthonous with some allochtonous components due to human intervention. Their role in geobiological processes requires further investigation.
\end{abstract}

Keywords: $\quad$ gypsum crystals, iron oxide crusts, hot springs, 16S rRNA, bacterial isolates, Naica

Received 27 November 2017; Revised 21 May 2018; Accepted 24 May 2018

Citation: $\quad$ Espino del Castillo A., Beraldi-Campesi H., Amador-Lemus P., Beltrán H.I. and Le Borgne S., 2018. Bacterial diversity associated with mineral substrates and hot springs from caves and tunnels of the Naica Underground System (Chihuahua, Mexico). International Journal of Speleology, 47 (2), 213-227. Tampa, FL (USA) ISSN 0392-6672

https://doi.org/10.5038/1827-806X.47.2.2161

\section{INTRODUCTION}

Deep subsurface environments (natural caves, tunnels, shafts, fractures, aquifers, mine systems) are integral ecosystems of the lithosphere, with exchanges of gases, matter, and life at different rates and magnitudes with surface environments and the atmosphere (Parkes et al., 2005; Barton \& Northup, 2007; Parkes et al., 2011; Kallmeyer \& Wagner, 2014). These environments bear important resources (water, ores, energy) and have attracted the attention of microbiologists in the last decades because they represent largely unknown pools of microbes with interesting biological activities and potential 
applications in mineral processing, exploration and bioremediation, among others (Colwell \& D'Hondt, 2013; Tomova et al., 2013).

Culture-dependent and -independent surveys of deep mines and caves worldwide have revealed the presence of complex and phylogenetically diverse prokaryotic microbial communities, comprising microbes with a variety of metabolic capabilities, such as sulfate-reducers, chemoheterotrophs, hydrogenoxidizers, thermophiles, and heavy-metal resistant organisms (Moser et al., 2003; Onstott et al., 2003; Barton \& Northup, 2007; Zhang et al., 2007a; Rastogi et al., 2009; Engel, 2010; Epure et al., 2014). The microbiota of Mexican subterranean environments has, however, been poorly explored.

In the last century, the Naica Underground System (NUS) located in the State of Chihuahua (Mexico) has been an important source of ores, mainly lead and zinc. Besides its industrial and economic relevance, it is also exceptional for its caves of giant selenite (gypsum, $\mathrm{CaSO}_{4} \cdot 2 \mathrm{H}_{2} \mathrm{O}$ ) crystals. Some of these can reach $>10 \mathrm{~m}$ in length and $>1 \mathrm{~m}$ in width, being thus the world's largest gypsum crystals. Other conspicuous and abundant chemical precipitates are also found on the inner walls of the caves. The most common are extensive iron oxide crusts, often mixed with other minerals, such as celestite $\left(\mathrm{SrSO}_{4}\right)$ and calcite $\left(\mathrm{CaCO}_{3}\right)$. Man-made tunnels provide direct access to the host rock, which is mainly composed of limestone and other minor minerals, such as sulfides, sulfates, as well as iron and manganese oxides (Forti et al., 2009; Forti \& Sanna, 2010). The presence of putative biogenic structures in iron oxide crusts suggests that microbes may play a role in the formation or modification of mineral deposits within the NUS (Forti \& Sanna, 2010). Ragon et al. (2013) have explored the microbial diversity of hydrothermal waters of the NUS using culture-independent methods. These authors detected a low bacterial and archaeal diversity in these waters and suggested that some of the retrieved sequences corresponded to thermophilic chemolithoautotrophs adapted to energy-limited environments. However, to date, there are no reports concerning the diversity of microorganisms present on solid mineral substrates of the NUS. Furthermore, no isolated microorganisms have been reported from this system, these are particularly valuable for experimentation on their geobiological capabilities.

Therefore, herein, we report on a survey of the bacterial diversity associated with conspicuous solid substrates (gypsum crystals and iron oxide crusts) and hot springs in natural caves and manmade tunnels of the NUS using culture-dependent and -independent methods. This is the first report on culturable bacteria from the NUS, some of them presenting biomineralization activities and, thus, a potential role in minerals transformation.

\section{MATERIALS AND METHODS}

\section{Site location and description}

Naica's entrance to the mine opens at 1,385 m a.s.1. and is located on the NE flank of the Sierra de Naica $\left(27.852470^{\circ}-105.496469^{\circ}\right)$ in Chihuahua, Mexico. Caves and tunnels occur from -120 to $-800 \mathrm{~m}$. The underground system formed from dissolution of the enclosing Mesozoic limestone of the Aurora Formation (Marin Herrera et al., 2006; Briceño-Prieto, 2011). The overall geology and hydrology of the NUS is described elsewhere (Garcia-Ruiz et al., 2007; Forti \& Sanna 2010; Garofalo et al., 2010; Badino et al., 2011; Briceño-Prieto, 2011).

\section{Sampling}

Samplings were carried out in two different events and, for logistical and access permissions constraints within the mine, it was not possible to sample the same sites. So, in 2009, samples were collected from three natural caves at $-290 \mathrm{~m}$ (Cueva de los Cristales, Ojo de la Reina, and Cueva del Tiburón) while in 2011 samples were collected from four mine tunnels with low or no mining activity at $-290,-430,-780$, and -790 m (Fig. 1-2, Table 1). Three types of substrates were sampled: a) gypsum crystals growing on the walls, b) iron oxide crusts covering calcareous walls; and c) hot springs (sulfated and calcic type waters) percolating in caves and outflowing hot springs in tunnels. One additional sulfide (galena-sphalerite-pyrite) sample was collected from a tunnel wall.

Rock and mineral substrates were sampled by scraping the surface (up to $1 \mathrm{~cm}$ deep) with sterile spatulas and chisels, and placing the fragments directly into sterile, $50 \mathrm{ml}$ centrifuge tubes. Hot spring water was collected into sterile plastic containers thoroughly rinsed with the same water before sampling. Nitrile gloves were used at all times, and tools were cleaned and flamed with alcohol before and after each sampling. Samples for cultures were stored at $45^{\circ} \mathrm{C}$ during transport and until use in the laboratory; samples for DNA extraction were stored at $-80^{\circ} \mathrm{C}$ until use. The mineralogy and chemical composition of the major and minor elements were determined by X-ray diffraction and X-ray fluorescence for each sample type (data not shown).

Sample codes used herein are based on the substrate type (gyp = gypsum; ox = iron oxides; $\mathbf{w}=$ water; sulf = sulfide) and collection site $(\mathbf{C C}=$ Cueva de los Cristales; OR = Ojo de la Reina $; \mathbf{C T}=$ Cueva del Tiburón; Tun = tunnel); numbers indicate depth below ground in meters. Gypsum crystals (gyp) and iron oxide crusts (ox) were collected from the $\mathbf{C C}, \mathbf{O R}$ and CT caves (gypCC, oxCC, gypOR, oxOR, gypCT, and oxCT, respectively) from outside the CT (gypTun290) and CC caves (oxCCTun290, ox+gypTun290) and outside the Cueva de las Velas (oxTun290) at $-290 \mathrm{~m}$ (Fig. 2A-D). Additional iron oxide crusts and sulfides (ox+gypTun430 and sulfTun430) were collected at $-430 \mathrm{~m}$, and one gypsum crystals sample from a fracture with flowing hot water at $-790 \mathrm{~m}$ (gypTun790) (Table 1 and Figs. 1A and 2F).

\section{Environmental DNA isolation and PCR-DGGE analysis}

Environmental DNA was isolated from $1 \mathrm{~g}$ of solid samples or $50 \mathrm{ml}$ of hot spring water, using a commercial isolation kit (UltraClean Soil DNA, 


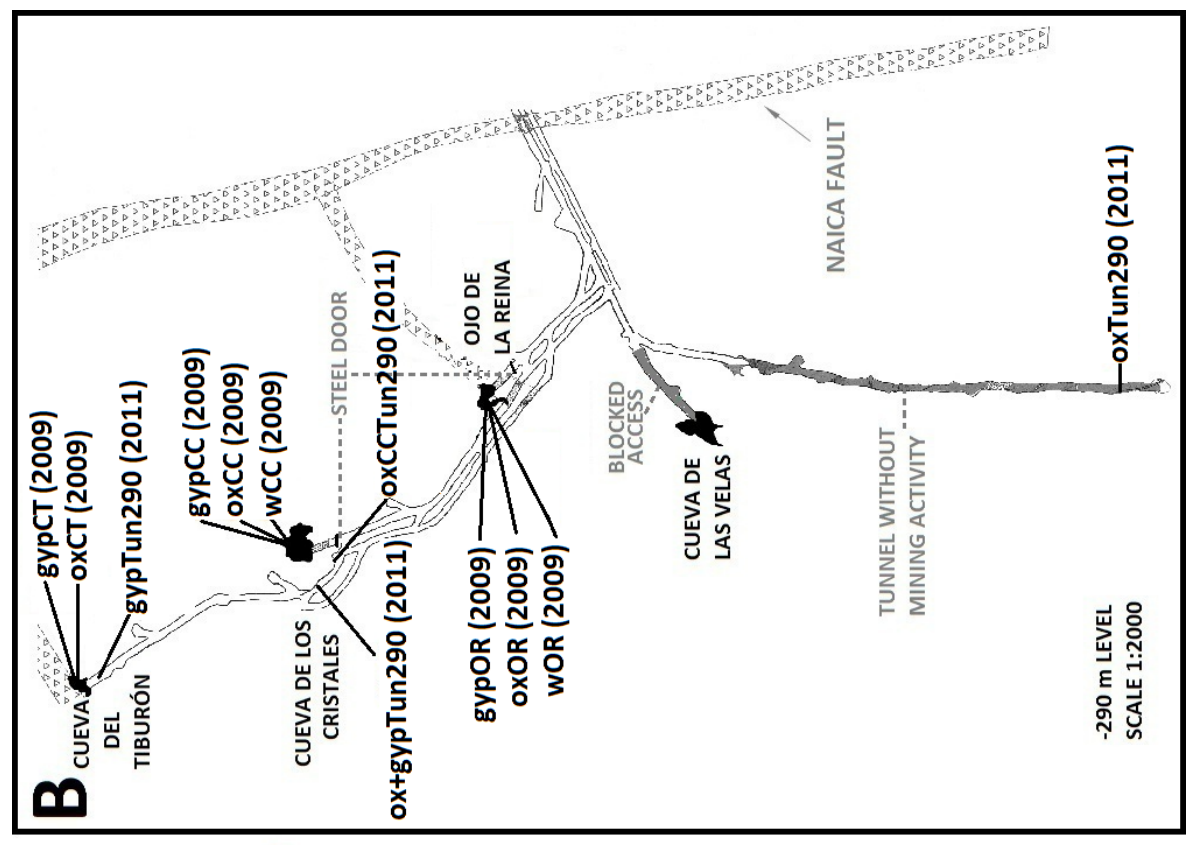

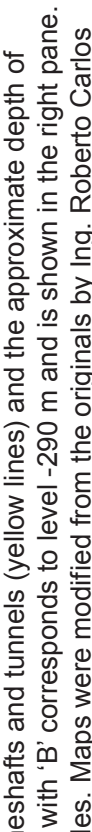

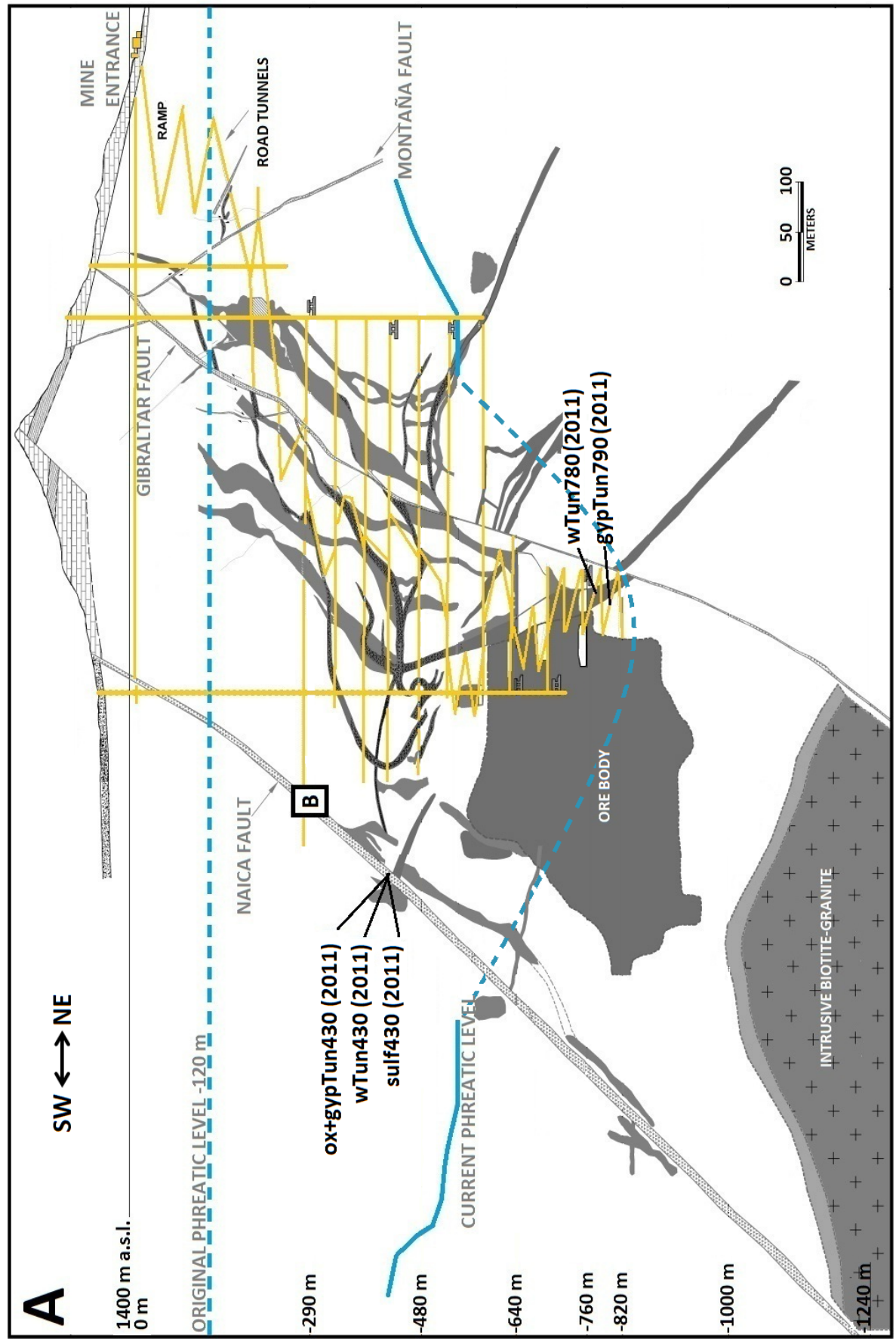

ह.

웜

वृ

क

$\sum \frac{\frac{0}{2}}{\frac{0}{\sigma}}$

है

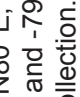

है

눙

०

之용

(1)

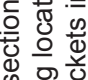

它

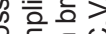

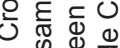

४

है क

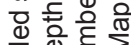

है응

政 के

도을 응

흉 다응

으 오응ㅇㅇ

든

क ष 0

之需焉

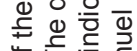

亩放

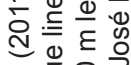

든 흥원 묻

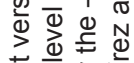

嵌.

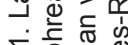

문을 
MoBio Laboratories Inc., Carlsbad CA), following the manufacturer's instructions. DNA quality and concentration were determined by electrophoresis in agarose gels and by spectrophotometry (ND-2000 Nanodrop spectrophotometer, Thermo Scientific, Wilmington DE). The V3 hypervariable region of the bacterial 16S rRNA was amplified by PCR using the GC-338F (5'- CGC CCG CCG CGC GCG GCG GGC GGG GCG GGG GCA CGG GGG GCC TAC GGG AGG CAG CAG -3’) and Univ529R (5)-ACC GCG GCK GCT GGC-3») primers (Muyzer et al., 1993). The PCR products from five replicate reactions were pooled, purified and concentrated into a final volume of $30 \mu 1$ using a DNA Clean \& Concentrator kit (Zymo Research Co., Irvine CA). The purified DNA ( 150 ng) was used for DGGE analysis in a Dcode System apparatus (BioRad Co, Hercules CA). The experimental conditions for DGGE were as follows: $8 \%(\mathrm{w} / \mathrm{v})$ polyacrylamide gels with a 40-60\% urea-formamide denaturing gradient, electrophoresis in $1 \mathrm{X}$ Tris-acetate EDTA (TAE) buffer at $60^{\circ} \mathrm{C}$ with a voltage of $55 \mathrm{~V}$ during $16 \mathrm{~h}$ and silver staining following the Bio-Rad silver stain protocol (http:/ /www.bio-rad.com/LifeScience/ pdf/Bulletin_9057.pdf).
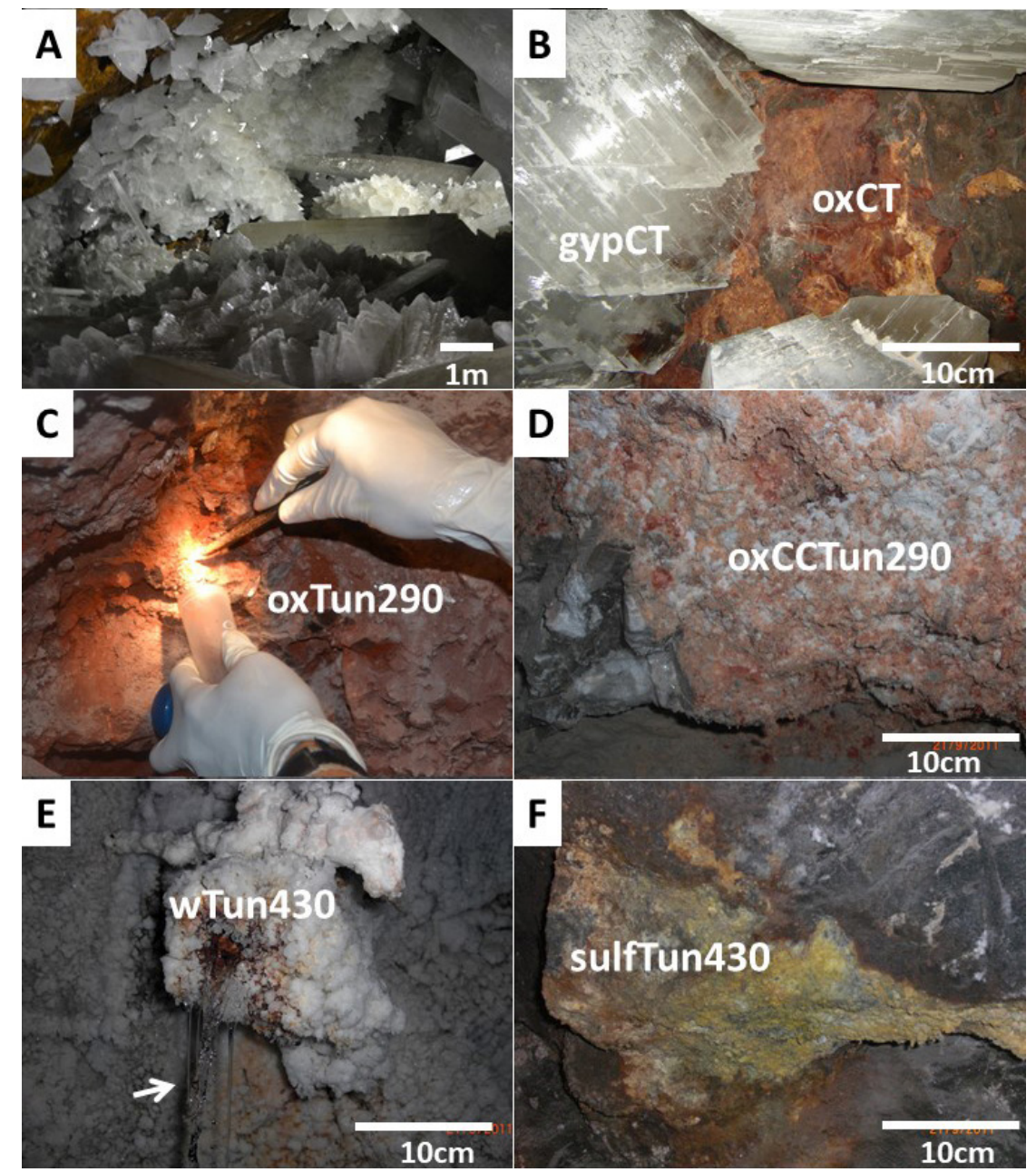

Fig. 2. General aspect of the sampled mineral surfaces and hot spring: A) giant Selenite (gypsum) crystals in Cueva de los Cristales [CC]; B) Close up of cave walls showing selenite crystals (gypCT) and well consolidated iron oxide crusts (oxCT) from CT; C) Semi-soft iron oxide deposit from a tunnel (oxTun290); D) Soft and hard iron oxide crusts with gypsum and carbonates from a tunnel (oxOCCTun290); E) Outflowing (arrow) hot spring from a tunnel (wTun430); F) Sulfide mineral deposit (galena-sphalerite-pyrite) from a tunnel (sulfTun430). See Table 1 for sample codes.

\section{Clustering analysis of DGGE fingerprints and sequencing of DGGE bands}

Digitized images of DGGE gels were used to quantify the number of bands per lane and their horizontal position with respect to neighboring bands using the ImageJ software (Rasband, 2012). Presence-absence matrices were then built from the DGGE banding patterns and used to calculate their hierarchical clustering using the Pearson correlation coefficient for similarity and complete linkage with the XLSTAT plugin v 2009.3.02 software for Microsoft Excel (www.xlstat.com). Selected bands were excised with sterile scalpels and soaked into $50 \mu \mathrm{l}$ of autoclaved MilliQ water overnight at $4^{\circ} \mathrm{C}$ for DNA elution. The eluted DNA was reamplified and purified as described above and sent out for sequencing. Retrieved sequences were compared with those available at the GenBank and Greengenes databases using the BLAST algorithm.

\section{Isolation and identification of bacteria}

Bacteria were isolated in the laboratory from $1 \mathrm{~g}$ of crushed solid samples or $1 \mathrm{ml}$ of aqueous samples, dissolved into $9 \mathrm{ml}$ of buffered saline phosphate (PBS; $137 \mathrm{mM} \mathrm{NaCl}, 2.7 \mathrm{mM} \mathrm{KCl}, 10 \mathrm{mM} \mathrm{Na} \mathrm{HPO}_{4}, 2 \mathrm{mM}$ $\mathrm{KH}_{2} \mathrm{PO}_{4}$ ) adjusted to $\mathrm{pH}$ 7.4. The suspensions were incubated for $48 \mathrm{~h}$ at $45^{\circ} \mathrm{C}$. Serial dilutions were spread onto solid media by the extension method using sterile 
Table 1. Type of samples collected at the NUS.

\begin{tabular}{|l|c|c|c|}
\hline \multicolumn{1}{|c|}{ Sample type } & Sample code & Collection year & Depth (m) \\
\hline Gypsum crystal & gypCC & 2009 & -290 \\
\hline Gypsum crystal & gypOR & 2009 & -290 \\
\hline Gypsum crystal & gypCT & 2009 & -290 \\
\hline Gypsum crystal & gypTun290 & 2011 & -290 \\
\hline Gypsum crystal & gypTun790 & 2011 & -790 \\
\hline Oxide crusts & oxCC & 2009 & -290 \\
\hline Oxide crusts & oxOR & 2009 & -290 \\
\hline Oxide crusts & oxCT & 2009 & -290 \\
\hline Oxide crusts & oxTun290 & 2011 & -290 \\
\hline Oxide crusts+carbonates & oxCCTun290 & 2011 & -290 \\
\hline Oxide crusts+ gypsum & ox+gypTun290 & 2011 & -290 \\
\hline Oxide crusts+ gyspum & ox+gypTun430 & 2011 & -430 \\
\hline Metal sulphides & sulfTun430 & 2011 & -430 \\
\hline Hot spring water ${ }^{* 1}$ & wTun430 & 2011 & -430 \\
\hline Hot spring water ${ }^{* 2}$ & wTun780 & 2011 & -780 \\
\hline Percolated water & wCC & 2009 & -290 \\
\hline Percolated water & wOR & 2009 & -290 \\
\hline
\end{tabular}

glass beads. The media used were nutrient agar (5 g/1 peptone, $1 \mathrm{~g} / 1$ meat extract, $2 \mathrm{~g} / 1$ yeast extract, 0.25 $\mathrm{g} / 1$ glucose, $5 \mathrm{~g} / 1 \mathrm{NaCl}$ ) and a modified PYG medium $(0.25 \mathrm{~g} / 1$ each of peptone, yeast extract and glucose, $20 \mathrm{mg} / 1 \mathrm{MnSO}_{4} \cdot \mathrm{H}_{2} \mathrm{O}$ ) (Adams \& Ghiorse, 1986). For isolation, all media were prepared with Naica's groundwater and noble agar as the gelling agent (BD DIFCO, Becton, Dickinson and Company, NJ, USA), and adjusted to $\mathrm{pH} 7.6$ before autoclaving. Plates were incubated at $45^{\circ} \mathrm{C}$ and growth was observed daily. The agar remained solid at $45-50^{\circ} \mathrm{C}$ however the plates had to be placed in sealed plastic bags to avoid drying of the medium at these temperatures. Colonies with different morphologies were purified by repetitive streaking on solid medium, and the obtained isolates were stored in $25 \%(\mathrm{v} / \mathrm{v})$ glycerol at $-80^{\circ} \mathrm{C}$. The bacteria were identified by PCR amplification of their 16S rRNA as previously described (López-Moreno et al., 2014). The obtained amplicons were sequenced at Macrogen Inc. (Seoul, Korea) and the obtained sequences were compared to the GenBank (NCBI) and GreenGenes databases using the basic local alignment search tool (BLAST) algorithm (Altschul et al., 1990).

\section{Calcium carbonate precipitation and iron(III) precipitation tests}

Isolates were tested for their ability to precipitate calcium and iron in solid medium, and to grow at $50-60^{\circ} \mathrm{C}$ in liquid media. For calcium precipitation, nutrient agar (5 g/1 peptone, $1 \mathrm{~g} / 1$ meat extract, 2 $\mathrm{g} / 1$ yeast extract, $0.25 \mathrm{~g} / 1$ glucose) was supplemented with $7.5 \mathrm{~g} / 1$ of $\mathrm{CaCl}_{2} \cdot \mathrm{H}_{2} \mathrm{O}$ (López-Moreno et al., 2014) and adjusted to $\mathrm{pH}$ 7.6. Calcium precipitating isolates formed visible crystals and flakes within or around colonies during a week of incubation at $45-50^{\circ} \mathrm{C}$ in solid media. For iron precipitation, nutrient agar was supplemented with $0.2 \mathrm{~g} / 1$ of $\mathrm{MgSO}_{4} \cdot 7 \mathrm{H}_{2} \mathrm{O}, 50$ $\mathrm{mg} / 1 \mathrm{CaCl}_{2} \cdot \mathrm{H}_{2} \mathrm{O}$ and $6 \mathrm{~g} / 1$ ferric ammonium citrate (Tuhela et al., 1993) and adjusted to $\mathrm{pH}$ 7.6. Iron
(III)-precipitating isolates produced rusty red-brown colonies within $48 \mathrm{~h}$ of incubation at $45-50^{\circ} \mathrm{C}$.

\section{Nucleotide sequence accession numbers}

The obtained nucleotide sequences are available at the GenBank database with the accession numbers shown in Tables 2 and 3 for DGGE bands and bacterial isolates, respectively.

\section{RESULTS}

\section{Substrates characteristics}

The sampled gypsum crystals were euedral, colorless, with tabular habit (Fig. 2A-B). Only the gypTun790 sample was mixed with carbonates. Iron oxide crusts were often mixed with carbonate and sulfate fragments from the walls of caves and tunnels (Fig. 2C-D). Iron crusts from the $\mathbf{C C}$ and $\mathbf{C T}$ caves were thicker (up to about $1 \mathrm{~cm}$ ) compared to those from OR (which only consisted of a thin iron patina on the host rock). It is assumed that the iron oxide crusts found at $-290 \mathrm{~m}$ were deposited before the giant gypsum crystals formed (Forti et al., 2009; BriceñoPrieto, 2011). Environmental parameters of the NUS, including temperature and relative humidity, have already been thoroughly studied (Badino, 2009; Badino et al., 2011). According to these authors, the NUS is characterized by a high relative humidity $(>80 \%)$ and temperatures above $44^{\circ} \mathrm{C}$. Although the mining activities inside the NUS have provoked a decrease in air temperature due to ventilation, this system is therefore still considered a thermophilic environment. The temperature of sampled hot spring water sources in the tunnels at the $-430 \mathrm{~m}$ and -780 $\mathrm{m}$ levels were around $52^{\circ} \mathrm{C}$ (Table 1 ) and their $\mathrm{pH}$ was 6.81 and 7.29 , respectively. Chemical characterization of the water has been previously reported showing that it is saturated with calcium sulfate and carbonates (Garcia-Ruiz et al., 2007; Briceño-Prieto, 2011). 


\section{Analysis of DGGE banding patterns}

Differences in DGGE band positions (Figs. 3A and $4 \mathrm{~A})$, resulted in distance matrices that separated samples collected in caves and tunnels as shown by the obtained dendrograms (Fig. 3B and 4B). The community profiles presented low likeness (<50\%) among clusters in their main branches, indicating heterogeneity between sampled substrates (gypsum crystals, iron oxide crusts, and hot springs). The grouping of hot spring samples was more cohesive regardless of their source (caves or tunnels). Interestingly, cluster analysis of the different mineral substrates and hot spring water from caves (Fig. 3B) segregated samples from the CT cave, which is a smaller hidden cave, without steel doors and more exposed to the effects of detonations and mining activity than the $\mathbf{C C}$ or OR caves (Fig. 1B). Likewise, the differences observed in the banding pattern of samples taken in $\mathbf{C C}$ and adjacent tunnels (Fig. 4B), could be due to periodic disturbances by tourism or mining activities. In addition, DGGE fingerprints displayed at least eight common band positions in all the samples despite their dissimilar substrate source and location (Fig. 3A and 4A), suggesting that they represented ubiquitous bacteria. The number of bands per sample ranged from 6 to 28 with several similar horizontal band positions across lanes. The gypTun790 sample, located under an outflowing hot spring, had the highest number of bands of all solid samples. This sample was possibly 'enriched' with bacteria from the water. In general the number of bands was higher for hot spring water samples and intermediate for iron oxide crusts, despite these being very porous (allowing for biomass accumulation) and of probable biogenic origin (Forti et al., 2009; Forti \& Sanna, 2010).
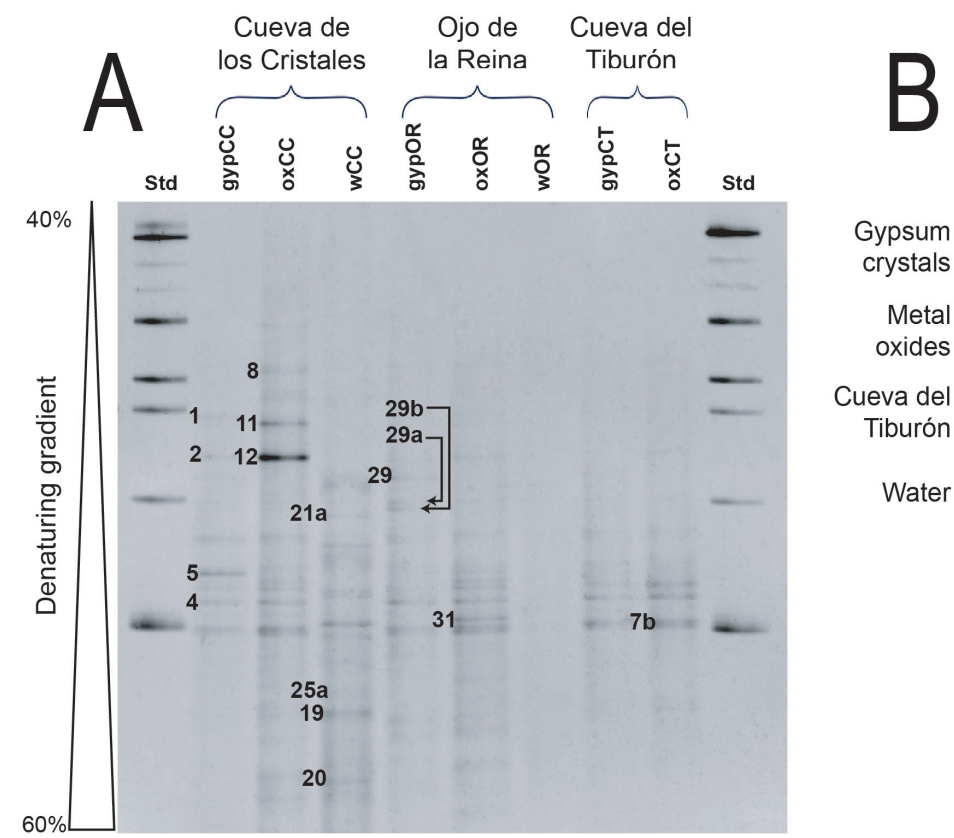

Fig. 3. DGGE fingerprint and corresponding cluster analysis from caves samples. A) DGGE fingerprint of samples from Cueva de los Cristales [CC], Ojo de la Reina [OR] and Cueva del Tiburon [CT]. Std corresponds to the100 bp molecular weight marker. Excised bands are indicated to the left of each band and with arrows; B) Dendrogram obtained from the cluster analysis of DGGE fingerprint. Green lines show clusters of solid substrates (gypsum crystals and iron oxides crusts) from caves. Red lines show clusters of solid and water samples. Blue lines show clusters of water samples (see Methods for details). See Table 1 for sample codes.

\section{Sequence analysis of DGGE bands}

A total of 43 sequences were obtained from representative bands excised from the DGGE gels. The obtained sequences were related to 12 bacterial genera belonging to 6 bacterial Phyla: Actinobacteria (Propionibacterium sp.), DeinococcusThermus (Meiothermus sp.), Firmicutes (Bacillus sp. and Staphylococcus sp.), Alphaproteobacteria (Sphingomonas sp. and Hyphomicrobium sp.), Betaproteobacteria (Delftia sp. and Comamonas sp.), and Gammaproteobacteria (Acinetobacter sp., Halomonas sp., Pseudomonas sp., and Hydrocarboniphaga sp.) (Table 2). These OTUs were present in both sampling campaigns except Delftia (Betaproteobacteria), which was only retrieved from iron oxide crusts inside caves CC and CT (collected in 2011). Common bands for all types of samples (e.g. bands B-14b, A-12, B-9, B-20, B-29, B-26, B-23c, B-24, B-25b, B-27, B-55a,b,c, B-56, B-57) (Figs. 3A-B and Table 2) corresponded to Comamonas, Acinetobacter, Hydrocarboniphaga and
Bacillus, indicating a continuous presence of these bacterial genera in the NUS despite samples being collected two years apart and in different locations inside the NUS. The sequences retrieved from calcium sulfate-rich substrates (either gypsum crystals or hot springs) mainly corresponded to Sphingomonas and Meiothermus. Less common sequences corresponded to Hyphomicrobium in the gyp'Tun790 sample, Delftia in iron oxide crusts from caves, Staphylococcus in the gypCC sample, Propionibacterium in some gypsum crystals and hot spring water samples, and some uncultured bacteria (Table 2). The bands corresponding to Meiothermus, Pseudomonas and Halomonas were only present in hot spring water samples (wTun430 and wTun780) and in a gypsum sample under a hot spring water seepage (gypTun790).

\section{Isolation and identification of bacteria}

Several heterotrophic bacterial isolates were obtained in pure culture from gypsum crystals, iron oxide crusts 


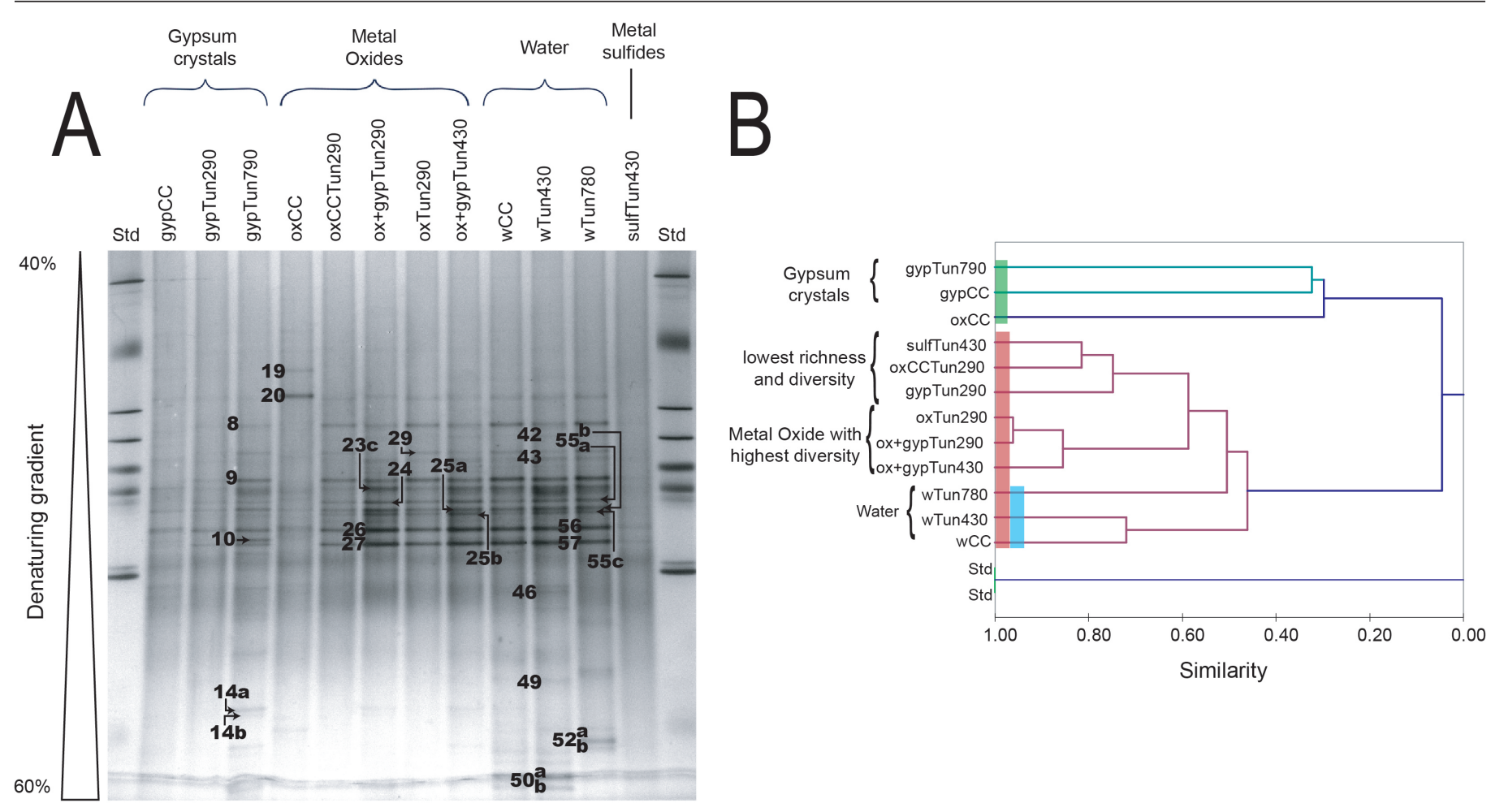

Fig. 4. DGGE fingerprint and corresponding cluster analysis from Cueva de los Cristales and mine tunnels. A) DGGE fingerprint of samples from Cueva de los Cristales and mine tunnels. Std corresponds to the100 bp molecular weight marker. Excised bands are indicated to the left of each band and with arrows; B) Dendrogram obtained from the cluster analysis of DGGE fingerprint. Green lines show clusters of solid substrates (gypsum crystals and iron oxides crusts) from caves. Red lines show clusters of solid and hot springs water samples. Blue lines show clusters of hot springs water samples (see Methods for details). See Table 1 for sample codes.

(or gypsum with iron oxides), and hot spring water samples (Table 3). Based on their 16S rRNA sequences, the isolates grouped within the phyla Firmicutes, Betaproteobacteria and Gammaproteobacteria (Table 3). The Firmicutes included Bacillus subtilis, Bacillus licheniformis, Bacillus oceanosediminis and Paenibacillus sp. Firmicutes were isolated from all sample types. The Betaproteobacteria included
Schlegelella aquatica and Cupriavidus sp. Schlegelella isolates were retrieved from gypsum and hot spring water samples but not from iron oxide crusts while Cupriavidus isolates were only obtained from iron oxide crusts. The Gammaproteobacteria included Pseudoxanthomonas taiwanensis and Lysobacter thermophilus obtained from hot spring water and gypsum crystals, respectively.

Table 2. Phylogenetic affiliations of DNA sequences retrieved in DGGE bands.

\begin{tabular}{|c|c|c|c|c|c|c|}
\hline Sample code & Phyla & Blast Identity ${ }^{a}$ & $\begin{array}{l}\text { Identity } \\
(\%)\end{array}$ & $\begin{array}{l}\text { Environmental source } \\
\text { of blasted match }\end{array}$ & $\begin{array}{l}\text { Accession } \\
\text { Number }\end{array}$ & Band $^{c}$ \\
\hline $\mathbf{w C C}$ & \multirow{3}{*}{ Actinobacteria } & $\begin{array}{c}\text { Uncultured bacterium } \\
\text { (JF935221) }\end{array}$ & 97 & $\begin{array}{l}\text { Clone. Alkaline hot } \\
\text { spring sediment }\end{array}$ & HG797141 & A-25a \\
\hline gypTun790 & & $\begin{array}{c}\text { Propionibacterium acnes } \\
\text { (AB540664) }\end{array}$ & 100 & Strain. Ditch sludge & HG797149 & B-14a \\
\hline wTun430 & & $\begin{array}{c}\text { Propionibacterium acnes } \\
\text { (AB540664) }\end{array}$ & 100 & Strain. Ditch sludge & HG797165 & B-50b \\
\hline wCC & \multirow{3}{*}{$\begin{array}{l}\text { Deinococcus- } \\
\text { Thermus }\end{array}$} & $\begin{array}{c}\text { Meiothermus timidus } \\
\text { (AJ871170) }\end{array}$ & 98 & Strain. Hot spring water & HG797138 & A-19 \\
\hline wTun430 & & $\begin{array}{l}\text { Meiothermus timidus } \\
\text { (AJ871170) }\end{array}$ & 99 & Hot spring water & HG797163-64 & B-49/B-50a \\
\hline $\mathbf{w C C}$ & & $\begin{array}{c}\text { Meiothermus sp. } \\
\text { (FN666194) }\end{array}$ & 99 & $\begin{array}{l}\text { Uncultured. Geothermal } \\
\text { springs }\end{array}$ & HG797139 & A-20 \\
\hline gypCC & \multirow{7}{*}{ Firmicutes } & $\begin{array}{c}\text { Staphylococcus sp. } \\
\text { (X86633) }\end{array}$ & 99 & $\begin{array}{l}\text { Strain. Deep subsurface } \\
\text { environment }\end{array}$ & HG797130 & A-1 \\
\hline oxOR & & Bacillus sp. (FJ889612) & 100 & $\begin{array}{l}\text { Strain. Psycrotolerant } \\
\text { from sea }\end{array}$ & HG797145 & A-31 \\
\hline ox+gypTun290 & & Bacillus sp. (KC809940) & 100 & $\begin{array}{l}\text { Strain. Heavy metal- } \\
\text { contaminated soil }\end{array}$ & HG797153-55 & $\begin{array}{c}\mathrm{B}-23 \mathrm{c} / \mathrm{B}-24 / \\
\mathrm{B}-25 \mathrm{a}\end{array}$ \\
\hline ox+gypTun290 & & Bacillus sp. (KC809940) & 99 & $\begin{array}{c}\text { Strain. Heavy metal- } \\
\text { contaminated soil }\end{array}$ & HG797156,58 & B-25/B-27 \\
\hline wTun430 & & Bacillus sp. (KF561879) & 99 & $\begin{array}{l}\text { Strain. Fresh water } \\
\text { sediment Mn(II)ox. }\end{array}$ & HG797161 & $\mathrm{B}-43$ \\
\hline wTun780 & & Bacillus sp. (KF576647) & 100 & $\begin{array}{l}\text { Strain. Marine from } \\
\text { xenobiotic sediment }\end{array}$ & HG797169 & B-55b \\
\hline wTun780 & & $\begin{array}{c}\text { Bacillus pseudofirmus } \\
\text { (HG513117) }\end{array}$ & 100 & $\begin{array}{l}\text { Strain. Extremophile } \\
\text { from soda lake }\end{array}$ & HG797168. & B-55a/B-56 \\
\hline
\end{tabular}




\begin{tabular}{|c|c|c|c|c|c|c|}
\hline wTun780 & \multirow{2}{*}{ Firmicutes } & $\begin{array}{l}\text { Bacillus subtilis } \\
\text { (KF574386) }\end{array}$ & 100 & $\begin{array}{l}\text { Strain. Arsenic } \\
\text { contaminated soil }\end{array}$ & HG797170 & B-55c \\
\hline wTun780 & & $\begin{array}{c}\text { Bacillus subtilis } \\
\text { (GQ302521) }\end{array}$ & 99 & Strain. Soil & HG797172 & B-57 \\
\hline gypcc & \multirow{4}{*}{$\begin{array}{c}\text { Alpha- } \\
\text { proteobacteria }\end{array}$} & $\begin{array}{l}\text { Sphingomonas sp. } \\
\text { (AB288317) }\end{array}$ & 99 & $\begin{array}{l}\text { Strain. Groundwater of } \\
\text { coal mine }\end{array}$ & HG797131-32 & A-2 / A-4 \\
\hline wTun430 & & $\begin{array}{c}\text { Sphingomonas sp. } \\
\text { (AB851323) }\end{array}$ & 99 & Strain. Agricultural soil & HG797160 & B-42 \\
\hline gypcc & & $\begin{array}{l}\text { Uncultured bacterium } \\
\text { (KC711257) }\end{array}$ & 99 & $\begin{array}{l}\text { Clone. Geothermal and } \\
\text { carbonic springs }\end{array}$ & HG797133 & A-5 \\
\hline gypTun790 & & $\begin{array}{l}\text { Hyphomicrobium sp. } \\
\text { (FJ711209) }\end{array}$ & 99 & $\begin{array}{l}\text { Strain. Stalactite of } \\
\text { carbonate cave }\end{array}$ & HG797148 & B-10 \\
\hline oxCT & & $\begin{array}{l}\text { Delftia tsuruhatensis } \\
\text { (GQ140326) }\end{array}$ & 99 & Strain. Calcarenite stone & HG797134 & $A-7 b$ \\
\hline oxCC & $\begin{array}{c}\text { Beta- } \\
\text { proteobacteria }\end{array}$ & $\begin{array}{l}\text { Delftia tsuruhatensis } \\
\text { (GQ140326) }\end{array}$ & 99 & Strain. Calcarenite stone & HG797151 & B-19 \\
\hline gypTun790 & & $\begin{array}{l}\text { Comamonas sp. } \\
\text { (FM877975) }\end{array}$ & 100 & $\begin{array}{l}\text { Strain. Groundwater } \\
\text { seep }\end{array}$ & HG797150 & B-14b \\
\hline oxCC & & $\begin{array}{l}\text { Acinetobacter sp. } \\
\text { (FJ821608) }\end{array}$ & 100 & $\begin{array}{c}\text { Strain. Hot spring } \\
\text { sediment }\end{array}$ & HG797135-37 & A-8/A-11/A-12 \\
\hline gypOR & & $\begin{array}{l}\text { Acinetobacter sp. } \\
\text { (FJ895355) }\end{array}$ & 99 & $\begin{array}{c}\text { Clone. High-temperature } \\
\text { petroleum reservoir }\end{array}$ & HG797143 & $\mathrm{A}-29^{\mathrm{a}}$ \\
\hline gypTun790 & & $\begin{array}{l}\text { Acinetobacter sp. } \\
\text { (FJ895355) }\end{array}$ & 100 & $\begin{array}{l}\text { Clone. High-temp. } \\
\text { petroleum reservoir }\end{array}$ & HG797147 & B-9 \\
\hline oxCC & & $\begin{array}{l}\text { Acinetobacter sp. } \\
\text { (FJ821608) }\end{array}$ & 100 & $\begin{array}{c}\text { Strain. Hot spring } \\
\text { sediment }\end{array}$ & HG797152 & B-20 \\
\hline oxTun290 & & $\begin{array}{l}\text { Acinetobacter sp. } \\
\text { (KC522315) }\end{array}$ & 100 & $\begin{array}{l}\text { Strain. EPS producer of } \\
\text { sugarcane }\end{array}$ & HG797159 & B-29 \\
\hline $\mathbf{w C C}$ & & $\begin{array}{c}\text { Uncultured Acinetobacter } \\
\text { sp. (KF511896) }\end{array}$ & 99 & $\begin{array}{c}\text { Clone. Cr (VI) } \\
\text { Contaminated soil }\end{array}$ & HG797140 & A-21a \\
\hline gypOR & $\begin{array}{c}\text { Gamma- } \\
\text { proteobacteria }\end{array}$ & $\begin{array}{c}\text { Uncultured } \\
\text { Pseudomonadaceae } \\
\text { (JN839761) }\end{array}$ & 97 & $\begin{array}{l}\text { Clone. Hypersaline } \\
\text { environments }\end{array}$ & HG797142 & A-29 \\
\hline gypOR & & $\begin{array}{c}\text { Pseudomonadaceae } \\
\text { bacterium (GU129051) }\end{array}$ & 97 & $\begin{array}{l}\text { Strain. Water from } \\
\text { oil bed. Aerobic } \\
\text { organotrophs }\end{array}$ & HG797144 & A-29b \\
\hline wTun780 & & $\begin{array}{c}\text { Pseudomonas sp. } \\
\text { (FJ877154) }\end{array}$ & 100 & $\begin{array}{c}\text { Strain. Soil polluted by } \\
\text { oil }\end{array}$ & HG797166-67 & B-52a/B-52b \\
\hline gypTun790 & & $\begin{array}{c}\text { Halomonas desiderata } \\
\text { (AB362300) }\end{array}$ & 100 & $\begin{array}{c}\text { Strain. Core sediment of } \\
\text { deep subsea floor }\end{array}$ & HG797146 & B-8 \\
\hline wTun430 & & $\begin{array}{l}\text { Uncultured Halomonas sp. } \\
\text { (KF051461) }\end{array}$ & 100 & $\begin{array}{l}\text { DGGE band. PAH- } \\
\text { contaminated site }\end{array}$ & HG797162 & B-46 \\
\hline ox+gypTun290 & & $\begin{array}{c}\text { Hydrocarboniphaga effusa } \\
\text { (JX177695) }\end{array}$ & 100 & $\begin{array}{l}\text { Strain. Baltic Sea } \\
\text { surface water }\end{array}$ & HG797157 & B-26 \\
\hline
\end{tabular}

${ }^{a}$ Reported accession numbers are from the GenBank database.

${ }^{b}$ Accession numbers of DGGE bands from this study in the GenBank database.

'See excised band number in Figs. 3A and B

\section{Calcium carbonate and iron(III) precipitation by bacterial isolates}

Calcium carbonate-precipitating isolates formed visible crystals or flakes within or around colonies after a week of incubation at $45^{\circ} \mathrm{C}$ in solid medium supplemented with $\mathrm{CaCl}_{2}$. All the Bacillus isolates could precipitate copious amounts of calcium carbonate as well as the Pseudoxanthomonas, Lysobacter, and Cupriavidus isolates, although to a much lesser extent in the case of Schlegelella and Cupriavidus. Brevibacillus and Paenibacillus could not precipitate calcium carbonate under the tested conditions. Some heterotrophic bacteria may precipitate poorly crystalline $\mathrm{Fe}(\mathrm{III})$-oxides via the utilization of carbon from Fe (III) organic complexes (in this case from ferric ammonium citrate) (Tuhela et al., 1993). All the Bacillus, Brevibacillus, and Cupriavidus strains could produce $\mathrm{Fe}(\mathrm{III})$ precipitates evidenced by a red-brown color in solid medium amended with ferric ammonium citrate (Fig. 5). Paenibacillus, Pseudoxanthomonas and Schlegelella isolates did not produce $\mathrm{Fe}(\mathrm{III})$ precipitates under these conditions.
Lysobacter did not grow in the medium amended with ferric ammonium citrate.

\section{DISCUSSION}

Natural caves and other subsurface environments are considered oligotrophic and in these systems, energy sources and nutrients for microbial growth normally enter as gases and condensates, soilderived aromatic and polyaromatic compounds, groundwater, and metal ions dissolved from rocks and minerals (Mulec, 2008). This energy and nutrient input can dramatically change due to human impact via polluted underground or percolating waters, infiltrations from impacted soils or air contaminated during tourist visitation and mining activities, all of which can carry allochtonous organic and inorganic matter and new microbial populations, altering indigenous microbial communities (Onstott et al., 2003, Mulec, 2008, Chelius et al., 2009, Rastogi et al., 2009, Adetutu et al., 2012, Griffin et al., 2014). The active exploitation of the Naica Mine initiated 
Table 3. Summary of bacterial isolates retrieved from the NUS.

\begin{tabular}{|c|c|c|c|c|c|c|c|c|c|}
\hline \multirow{2}{*}{ Sample } & \multirow{2}{*}{ Phyla } & \multirow{2}{*}{ Closest match } & \multirow{2}{*}{$\begin{array}{c}\text { Identity } \\
(\%)\end{array}$} & \multirow{2}{*}{$\begin{array}{l}\text { Environmental } \\
\text { source of blasted } \\
\text { match }\end{array}$} & \multirow{2}{*}{$\begin{array}{c}\text { Accession } \\
\text { Number }^{b}\end{array}$} & \multirow{2}{*}{\begin{tabular}{|c|}
$\begin{array}{c}\text { Max } \\
\text { growth }\end{array}$ \\
T $\left({ }^{\circ} \mathbf{C}\right)^{c}$
\end{tabular}} & \multirow{2}{*}{$\begin{array}{l}\text { Strain } \\
\text { code }\end{array}$} & \multicolumn{2}{|c|}{$\begin{array}{c}\text { Precipitation } \\
\text { tests }\end{array}$} \\
\hline & & & & & & & & $\mathbf{C a}$ & $\mathrm{Fe}$ (III) \\
\hline gypCc & \multirow{8}{*}{ Firmicutes } & $\begin{array}{l}\text { Bacillus subtilis } \\
\text { (MF966263) }\end{array}$ & 100 & $\begin{array}{l}\text { Strain. Lead and zinc } \\
\text { mine }\end{array}$ & MG282294 & 55 & Cc1.1a & $\checkmark$ & $\checkmark$ \\
\hline oxCC & & $\begin{array}{l}\text { Bacillus subtilis } \\
\text { (KY010273) }\end{array}$ & 100 & $\begin{array}{l}\text { Strain. Soil with } \\
\text { petroleum }\end{array}$ & MG282296 & 55 & Cp1.15 & $\checkmark$ & $\checkmark$ \\
\hline wCC & & $\begin{array}{l}\text { Bacillus subtilis } \\
\text { (KM822599) }\end{array}$ & 100 & Strain. Soil & MG282293 & 55 & Ca1.7b & $\checkmark$ & $\checkmark$ \\
\hline oxCC & & $\begin{array}{c}\text { Bacillus licheniformis } \\
\text { (HQ143568) }\end{array}$ & 99 & Strain. Soil & MG282295 & 58 & Cp 1.5 & $\checkmark$ & $\checkmark$ \\
\hline wCC & & $\begin{array}{c}\text { Bacillus licheniformis } \\
\text { (KM893455) }\end{array}$ & 99 & $\begin{array}{l}\text { Strain. Contaminated } \\
\text { soil }\end{array}$ & MG282292 & 58 & Ca1.1 & $\checkmark$ & $\checkmark$ \\
\hline ox+gypTun430 & & $\begin{array}{c}\text { Bacillus } \\
\text { oceanisediminis } \\
\text { (KX007772) }\end{array}$ & 99 & $\begin{array}{l}\text { Strain. Soil from gold } \\
\text { mine }\end{array}$ & MG282302 & 55 & NOy 4.4 & $\checkmark$ & $\checkmark$ \\
\hline ox+gypTun430 & & $\begin{array}{l}\text { Brevibacillus } \\
\text { limnophilus } \\
\text { (NR_024822) } \\
\end{array}$ & 99 & Strain. Thermophilic & MG282301 & 45 & NOy 4.2 & - & $\checkmark$ \\
\hline ox+gypTun430 & & $\begin{array}{c}\text { Paenibacillus sp. } \\
\text { (CP013653) }\end{array}$ & 99 & $\begin{array}{l}\text { Strain. Soil- } \\
\text { Thermophile }\end{array}$ & MG282304 & 58 & Oy 4.3 & - & - \\
\hline gypTun790 & \multirow{7}{*}{$\begin{array}{c}\text { Beta- } \\
\text { proteobacteria }\end{array}$} & $\begin{array}{c}\text { Schlegelella aquatica } \\
\text { (FR774570) }\end{array}$ & 100 & Strain. Paper mill & MG282291 & 50 & C7.1 & $\checkmark$ & - \\
\hline gypTun790 & & $\begin{array}{c}\text { Schlegelella aquatica } \\
\text { (FR774570) }\end{array}$ & 100 & Strain. Paper mill & MG282298 & 50 & $\mathrm{NC} 7.1$ & $\checkmark$ & - \\
\hline wTun430 & & $\begin{array}{c}\text { Schlegelella aquatica } \\
\text { (FR774570) }\end{array}$ & 99 & Strain. Paper mill & MG282286 & 50 & A 4.1 & $\checkmark$ & - \\
\hline wTun430 & & $\begin{array}{c}\text { Schlegelella } s p . \\
\text { (FR774567) }\end{array}$ & 99 & Strain. Paper mill & MG282287 & 50 & A 4.4 & $\checkmark$ & - \\
\hline wTun430 & & $\begin{array}{l}\text { Schlegelella sp. } \\
\text { (FR774567) }\end{array}$ & 99 & Strain. Paper mill & MG282290 & 50 & A4.9 & $\checkmark$ & - \\
\hline wTun430 & & $\begin{array}{l}\text { Schlegelella sp. } \\
\text { (FR774567) }\end{array}$ & 100 & Strain. Paper mill & MG282297 & 58 & NA4.3 & $\checkmark$ & - \\
\hline \multirow[t]{2}{*}{ oxTun290 } & & $\begin{array}{l}\text { Cupriavidus } \\
\text { taiwanensis } \\
\text { (EU915711) }\end{array}$ & 95 & $\begin{array}{l}\text { Strain. Without } \\
\text { source information }\end{array}$ & MG282303 & 50 & OV2.1 & $\checkmark$ & $\checkmark$ \\
\hline & & $\begin{array}{l}\text { Cupriavidus } \\
\text { taiwanensis } \\
\text { (EU915711) }\end{array}$ & 95 & $\begin{array}{l}\text { Strain. Without } \\
\text { source information }\end{array}$ & MG282300 & 50 & NOV2.5 & $\checkmark$ & $\checkmark$ \\
\hline wTun430 & \multirow{2}{*}{$\begin{array}{c}\text { Gamma- } \\
\text { proteobacteria }\end{array}$} & $\begin{array}{c}\text { Pseudoxanthomonas } \\
\text { taiwanensis } \\
\text { (NR_025198) }\end{array}$ & 100 & $\begin{array}{l}\text { Strain. Thermophilic } \\
\text { from hot springs }\end{array}$ & MG282288 & 55 & A $4.5 \mathrm{a}$ & $\checkmark$ & - \\
\hline wTun430 & & $\begin{array}{c}\text { Pseudoxanthomonas } \\
\text { taiwanensis } \\
\text { (NR_025198) }\end{array}$ & 99 & $\begin{array}{l}\text { Strain. Thermophilic } \\
\text { from hot springs }\end{array}$ & MG282289 & 55 & A $4.5 \mathrm{~m}$ & $\checkmark$ & - \\
\hline gypTun790 & & $\begin{array}{c}\text { Lysobacter } \\
\text { thermophilus } \\
\text { (NR_109621) }\end{array}$ & 99 & $\begin{array}{l}\text { Strain. Geothermal } \\
\text { soil }\end{array}$ & MG2822 & 55 & $\mathrm{NC} 7.4 \mathrm{a}$ & $\checkmark$ & NG \\
\hline
\end{tabular}

${ }^{a}$ Accession numbers of the closest match in GenBank

${ }^{\mathrm{b}}$ Accession numbers of the isolates in GenBank

${ }^{\mathrm{c}}$ Growth in liquid nutrient media; NG = No Growth

in 1900 and groundwater pumping started in the 1970s (Marin Herrera et al., 2006) exposing rocks and minerals below $150 \mathrm{~m}$. After the giant crystals were discovered at the $-290 \mathrm{~m}$ level in year 2000, human presence became more frequent inside the caves and adjacent tunnels, followed by nearly four years (2006-2009) of intense documentary filming activities (Badino, 2009). These activities at different depths probably promoted contamination from the surface to the subsurface and across natural caves and artificial tunnels, influencing microbial diversity and distribution. The existence of human-associated bacteria in caves has been noted before (Campbell et al., 2011) and could therefore be expected in the NUS, especially in locations with continuous human visits or mining activities in touristic caves and tunnels. The occasional presence of crickets and bats may also be of importance. Thus, in contrast to Ragon et al. (2013) who suggested that only indigenous microbes thrived in a deep subsurface aquifer of the NUS, the bacterial communities analyzed here seemed to be mixed communities of both native and allochthonous organisms.

The clustering analysis of DGGE profiles showed a segregation of bacterial communities from caves and tunnels, and a correlation according to their substrate, suggesting that the bacterial community composition was similar between substrates of the same type (gypsum crystals, iron oxide crusts or hot springs), despite such samples being collected at different times, depths and locations. Similar banding patterns for samples collected two years apart suggest little or no variation in the community composition regardless of their substrate, even with continuous and ongoing mining activities and tourist visitations. This seems consistent with a relatively steady environment expected for underground systems (Barton \& Northup, 2007). Combined environmental (temperature, water chemistry) and geochemical (types of minerals) factors may influence the development and overall distribution of microbial communities in artificial tunnels and natural caves in the NUS. The main 


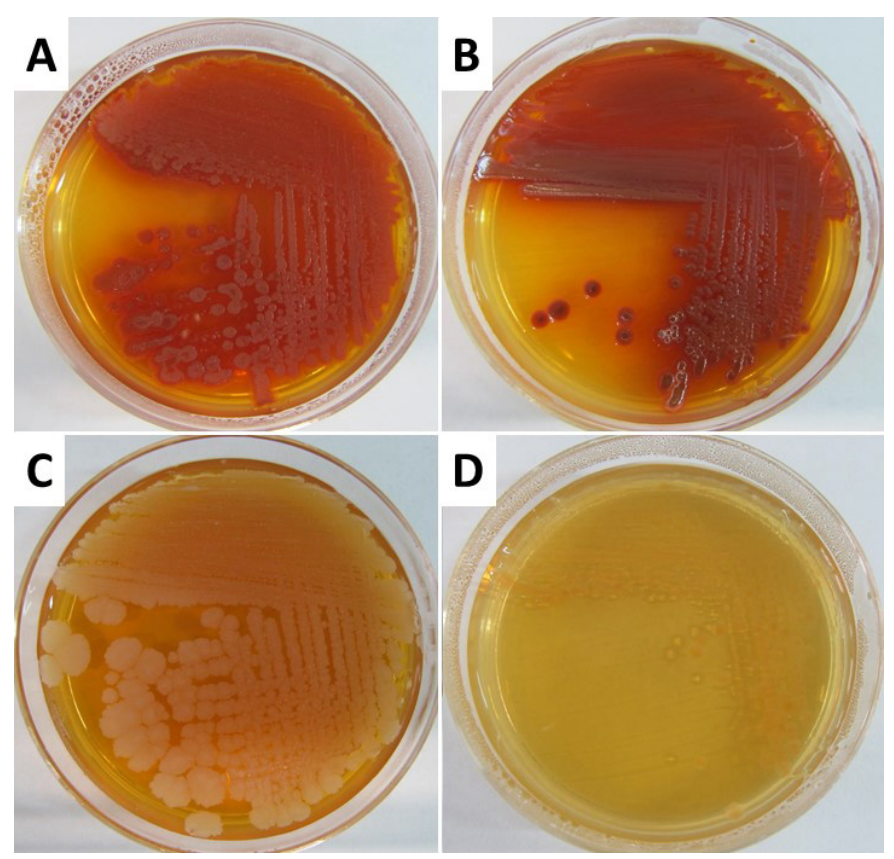

Fig. 5. Fe(III) precipitation tests. A and B) Positive $\mathrm{Fe}(\mathrm{III})$ precipitation by Bacillus licheniformis (Str. Cp1.5) and Cupriavidus sp. (Str. NOV2.5), respectively. $\mathrm{C}$ and D) Negative $\mathrm{Fe}(\mathrm{III})$ precipitation by Bacillus subtilis (Str. Cp1.15), and Pseudoxanthomonas taiwanensis (Str. A4.5a), respectively.

disadvantages of DGGE are that it sometimes detects only the top 1\% population (Muyzer et al., 1993); intra-specific and intra-isolate microheterogeneity in ribosomal sequences can produce different bands for a same bacterial species (Nakatsu et al., 2000); different DNA sequences of different bacterial species can migrate at the same position (Muyzer et al., 2004). However, DGGE fingerprints are advantageous when multiple samples are processed and are suitable for comparing patterns across different sites, allowing an exploratory approach and a quick "view" of microbial communities composition (Fry et al., 2006; Cleary et al., 2012). Although only a small proportion of bacterial taxa can be successfully retrieved by PCRDGGE techniques, the diversity recovered here provides valuable information about the bacteria present on different substrates, depths, locations and environmental conditions at the NUS.

Concerning the Firmicutes, Bacillus species were detected by DGGE and isolated from all types of samples (gypsum crystals, iron oxide crusts, and water samples) at different sampling sites in the NUS. Nevertheless, Bacillus spp. were not detected by Ragon et al. (2013) although these authors detected 2 OTUs close to Paenibacillus, which was isolated in the present study from an iron oxide crust sample together with Brevibacillus sp. Under laboratory conditions the Bacillus isolates precipitated Fe(III) and copious amounts of calcium minerals. Bacillus spp. are known for their ability to precipitate calciumcontaining minerals (calcite, aragonite and gypsum) both in natural environments and under laboratory conditions (Barabesi et al., 2007; Baskar et al., 2009; Achal et al., 2010; López-Moreno et al., 2014). It has been suggested that Bacillus may induce calcite precipitation in speleothems and gypsum in cave walls (Baskar et al., 2009). Additionally, both Paenibacillus and Brevibacillus have been previously reported from Fe(III)-reducing microbial communities in Uranium(VI) contaminated sediments (North et al., 2004). Particularly, Paenibacillus sp. has the ability to reduce soluble Fe(III) complexes (Ahmed et al., 2012) and may play a similar role in the NUS. Another Firmicutes, Staphylococcus sp., was detected by DGGE in the gypCC sample from the $\mathrm{CC}$ cave (the most visited cave). Staphylococcus has also been previously reported in caves and mines (Zhang et al., 2007a; Griffin et al., 2014). Bacillus and Staphyloccocus have long been considered as human indicator bacteria in caves together with Escherichia coli (Lavoie \& Northup, 2006). Staphylococcus belongs to the list of genera of human origin according to Human Microbiome Project Consortium and has been repeatedly associated to human contamination in cave environments (Griffin et al., 2014; Leuko et al., 2017). Thus, the fact that several of these Firmicutes were detected may reflect a degree of human disturbance. However, concerning Bacillus, this genus has also been considered indigenous in other studies (Spilde et al., 2005; Mulec, 2008; Baskar et al., 2009; Adetutu et al., 2012). For instance, halotolerant $B$. licheniformis isolates have been obtained from subsurface environments (Yakimov et al., 1995) including thermotolerant varieties. Bacillus sp. exhibiting high tolerance to $\mathrm{Pb}$ toxicity has been detected in mine tailings (Zhang et al., 2007b; Govarthanan et al., 2013) and has also been associated with biomineralization processes (bioaccumulation and solubilization) of metallic ions such as copper, lead, cadmium and zinc (Zastrow \& Straube, 1991; da Costa \& Duta, 2001). The presence of Bacillus sp. and their potential role in biogeochemical processes in the NUS needs to be further investigated.

Here, Hyphomicrobium sp. and Sphingomonas sp. (Alphaproteobacteria) were found by PCR-DGGE in gypsum crystals (gypTun290 and gypCC samples, respectively) as well as in hot spring water at -430 $\mathrm{m}$ for Sphingomonas. Hyphomicrobium has been previously detected in ferromanganese deposits in cave crusts and stromatolites, where it is thought to influence iron/manganese redox processes (Northup et al., 2003; Engel, 2010; Lozano \& Rossi, 2012). It has also been found as a major component of bacterial communities in moonmilk deposits, a cave and mine deposit constituted by hydrated carbonate crystals (Portillo \& Gonzalez, 2011)ÿ. Sphingomonas has also been found in water pools and sediments of caves and mines (Moser et al., 2003; Campbell et al., 2011; Adetutu et al., 2012). Although Ragon et al. (2013) did not detect Hyphomicrobium, they found several OTUs related to Paracoccus and Sphingomonas, this last one consistent with our results. As Hyphomicrobium, Paracoccus is a metabolically versatile bacterium capable of methylotrophy, chemolithotrophy on sulfur and denitrification, all of which are relevant metabolic processes in cave systems (Kumaresan et al., 2015).

The genus Delftia sp. (Betaproteobacteria), detected by DGGE in iron oxide crusts in the $\mathbf{C C}$ and $\mathbf{C T}$ caves, was also reported by Ragon et al. (2013) in hot spring water. A Delftia strain capable of zinc and lead biosorption was isolated from mine tailings, which is a 
related environment (Bautista-Hernández et al., 2012) and this genus seems to be common in natural caves (Barton et al., 2007). Coincidentally, Cupriavidus isolates, previously Ralstonia (Betaproteobacteria), capable to produce $\mathrm{Fe}$ (III) precipitates in solid medium at $45^{\circ} \mathrm{C}$ were obtained from iron oxide crusts at the $-290 \mathrm{~m}$ site. Ralstonia has been isolated from highly human impacted rock surfaces in a limestone cave (Ikner et al., 2007). Both Delftia and Cupriavidus are well known for their resistance to heavy metals and their ability to produce siderophores (Diels et al., 2009; Ubalde et al., 2012). Delftia was also reported to play a role in the formation of gold nuggets together with Cupriavidus metallidurans (Reith et al., 2010). Another Betaproteobacteria, Comamonas sp., was detected here by DGGE in a gypsum crystal sample located under a hot spring outflow. Comamonas have been found in speleosols (cave soils) and associated to iron, manganese, lead, cadmium and other metallic deposits (Spilde et al., 2005; Barton et al., 2007; Zhang et al., 2007b). Finally, within the Betaproteobacteria, two isolates of Schlegelella were obtained from gypsum crystals and hot spring waters that can precipitate calcium minerals under laboratory conditions at $45^{\circ} \mathrm{C}$. The Schlegelella genus comprises two moderately thermophilic species (optimum growth at $45-50^{\circ} \mathrm{C}$ ): S. thermodepolymerans (Elbanna et al., 2003) and $S$. aquatica (Chou et al., 2006) recovered from activated sludge under thermophilic conditions and a hot spring, respectively. To our knowledge, Schlegelella has not been reported from caves before and Ragon et al. (2013) did not retrieve this genus in their $16 \mathrm{~S}$ clone library study although the characteristics of this microorganism are consistent with a hot spring environment. In their study, Ragon et al. (2013) report that Bacteria were dominated by Betaproteobacteria, which is somehow consistent with the present DGGE and culturing results.

Several Gammaproteobacteria were detected by PCR-DGGE, as for example, Hydrocarboniphaga sp. in an iron oxide-gypsum sample and Acinetobacter sp. in iron oxide crusts and gypsum in caves and tunnels. These genera have been previously found in subsurface environments (Jimenez, 1990; Webster et al., 2006; Barton et al., 2007; Zhang et al., 2007b; Jones et al., 2008; Adetutu et al., 2012; Rusznyák et al., 2012) being Acinetobacter the most frequently reported, generally in non-disturbed areas of caves, i.e., inaccessible to tourists (Adetutu et al., 2012; Rusznyák et al., 2012; Griffin et al., 2014) although some authors also report it as a potential pathogen possibly translocated into caves by human and animal visitors (Tomova et al., 2013). Halomonas desiderata (detected in gypsum crystals by DGGE) is a moderately halophilic bacterium with ability to precipitate magnesium and calcium carbonates (Rivadeneyra et al., 1998), both widespread minerals in the NUS. Pseudomonas sp. (also detected by DGGE in gypsum crystals and hot springs) is a cosmopolitan, aerobic metal tolerant bacterium that has also been found in caves and mines (Jimenez, 1990; Cho et al., 2003; Onstott et al., 2003; Spilde et al., 2005; Zhang et al., 2007a; Adetutu et al., 2012; Rusznyák et al., 2012) and associated to the formation of moonmilk (Portillo $\&$ Gonzalez, 2011). Some studies have reported the presence of Pseudomonas in sites impacted by human visitation (Ikner et al., 2007; Griffin et al., 2014) while others detected it in pristine caves (Rusznyák et al., 2012) and in association to manganese oxide deposits deep into caves (Leuko et al., 2017). Several Gammaproteobacteria, were isolated here, namely Pseudoxanthomonas and Lysobacter species, from hot spring samples and from a gypsum crystal under hot spring flow, respectively. Pseudoxanthomonas taiwanensis and Lysobacter thermophilus are thermophilic species already isolated from hot springs (Chen et al., 2002) and geothermal soils (Wei et al., 2012) which coincide with some of the environmental parameters found in the NUS. Lysobacter has been isolated from cave environments both from high and low human impact sites (Ikner et al., 2007; Herzog Velijonka et al., 2014). Both the Pseudoxanthomonas and Lysobacter isolates could precipitate calcium minerals and grow at $45-55^{\circ} \mathrm{C}$ under laboratory conditions. These features make the presence of these two genera consistent with the environmental conditions at the NUS, with interesting biogeochemical potential in this system. Contrastively, Ragon et al. (2013) did not detect any Gammaproteobacteria in their study.

The genus Meiothermus (Deinococcus-Thermus) was only detected in water samples (wCC and wTun430). It is a moderately thermophile $\left(50-65^{\circ} \mathrm{C}\right)$ heterotroph, generally found in neutral and alkaline hot springs. It has been associated to the formation of speleothems in caves, geothermal mines (Spear et al., 2007), and geothermal steam vents (Benson et al., 2011). Finally, members of the Actinobacteria (detected in gypsum crystals and hot springs in caves and tunnels) have also been found in caves and mines (Zhang et al., 2007a; Rastogi et al., 2009), and may have a role in carbonate precipitation (Cuezva et al., 2012). The genus Propionibacterium sp. has been found associated with bioespeleogenesis at a sulfide rich cave hot spring (Barton \& Luiszer, 2005) and moonmilk deposits (Portillo \& Gonzalez, 2011). Propionibacterium is a major inhabitant of the human adult skin that belongs to the list of genera of human origin in caves (Griffin et al., 2014; Leuko et al., 2017). Again, in contrast, members of the DeinococcusThermus and Actinobacteria, as, those detected here, were not reported by Ragon et al. (2013).

\section{CONCLUSIONS}

PCR-DGGE techniques and culturing showed that bacteria are conspicuous throughout the NUS and revealed the presence of bacteria affiliated to the Actinobacteria, Deinococcus-Thermus, Firmicutes, Alphaproteobacteria, Betaproteobacteria, and Gammaproteobacteria in mineral substrates and hot springs water samples in caves and tunnels at different depths and locations of the NUS. Bacteria within the Deinococcus-Thermus and Actinobacteria lineages were only detected by DGGE in hot springs water samples. 
Most of these results are somehow consistent with those obtained by Ragon et al. (2013) considering different sampling events, substrates and depths within the NUS and the different methodology used (16S clone library). Ragon et al. (2013) focused on the microbial diversity of saline hydrothermal waters at $-700-760 \mathrm{~m}$ and detected bacteria belonging to the Candidate Phyla OP3, Firmicutes, Alpha, and Betaproteobacteria. They did not find Gammaproteobacteria and concluded that most of the detected lineages appeared to be autochthonous. The microbial ecosystem of the NUS is probably not so isolated and microbial communities in Naica may contain both indigenous and allochthonous organisms, considering that natural caves and human-made tunnels have been impacted by human activities. Most of the detected bacteria (isolates or DGGE bands) were related to organisms previously found in subsurface environments, hydrothermal springs, and heavy metal-contaminated mine tails. The ability of the obtained isolates to precipitate calcium and Fe(III) minerals may indicate a possible contribution in biomineralization processes inside the NUS. However, the influence of the detected bacteria in the formation and alteration of minerals and groundwater chemistry in the NUS is not known and requires further studies.

\section{ACKNOWLEDGMENTS}

We thank Eng. Roberto Carlos Reyes-Ramírez, Eng. Roberto Villasuso, and Minera Maple S.A. de C.V. (Compañía Peñoles) for facilitating maps, field studies, and access to the mine; Chem. Ma. Pilar Aliaga Campuzano (CGEO-UNAM), Eng. Fabiola Ansara Olivera (ITESM) and Biol. Pedro Westendarp Ortega (FC-UNAM) for their assistance in the field; Dr. Juan B. Morales-Malacara (FC-UNAM) for financing the first visit to Naica; Dra. Patricia Lappe for providing temporary facilities; Dr. Angélica López Moreno (UAM-C) for support with DGGE techniques; Drs. Juan Pablo Bernal Uruchurtu (CGEO-UNAM) for comments on the manuscript and technical support; Dr. Teresa Pi Puig and Chems. Rufino Lozano Santa Cruz and Patricia Girón García (IGL-UNAM) for XRD and XRF analyses; Adriana Espino del Castillo received a scholarship from CONACyT (CVU No. 412507) and funding from the Doctorado en Ciencias Biológicas y de la Salud de la Universidad Autónoma Metropolitana (Unidades Cuajimalpa, Iztapalapa y Xochimilco). The authors acknowledge the constant funding from the Universidad Autónoma Metropolitana-Unidad Cuajimalpa and several other funding sources to S. Le Borgne, from the CONACyT (Project 205981) and PAPIIT-DGAPA (Project IA103415) to H. BeraldiCampesi and from the CONACyT (Project 0243224) to H. I. Beltran. Finally, we wish to thank the reviewers for their constructive comments and suggestions.

\section{REFERENCES}

Achal V., Mukherjee A. \& Reddy M.S., 2010 Characterization of two urease-producing and calcifying
Bacillus spp. isolated from cement. Journal of Microbiology and Biotechnology, 20 (11): 1571-1576. https://doi.org/10.4014/jmb.1006.06032

Adams L.F. \& Ghiorse W.C., 1986 - Physiology and ultrastructure of Leptothrix discophora SS-1. Archives of Microbiology, 145 (2): 126-135. https://doi.org/10.1007/BF00446769

Adetutu E.M., Thorpe K., Shahsavari E., Bourne S., Cao X.S., Fard R.M.N., Kirby G. \& Ball A.S., 2012 Bacterial community survey of sediments at Naracoorte Caves, Australia. International Journal of Speleology, 41 (2): 137-147.

https://doi.org/10.5038/1827-806X.41.2.2

Ahmed B., Cao B., McLean J.S., Ica T., Dohnalkova A., Istanbullu O., Paksoy A., Fredrickson J.K. \& Beyenal H., 2012 - Fe(III) reduction and U(VI) immobilization by Paenibacillus sp. strain 300A, isolated from Hanford 300A subsurface sediments. Applied and Environmental Microbiology, 78 (22): 8001-8009.

https://doi.org/10.1128/AEM.01844-12

Altschul S.F., Gish W., Miller W., Myers E.W. \& Lipman D.J., 1990 - Basic local alignment search tool. Journal of Molecular Biology, 215 (3): 403-410. https://doi.org/10.1016/S0022-2836(05)80360-2

Badino G., 2009 - The Cueva de los Cristales Micrometeorology. In: White W.B. (Ed.), Proceedings of the $15^{\text {th }}$ International Congress of Speleology, Kerrville, p. 1407-1412.

Badino G., Calaforra J.M., Forti P., Garofalo P. \& Sanna L., 2011 - The present day genesis and evolution of cave minerals inside the Ojo de la Reina Cave (Naica Mine, Mexico). International Journal of Speleology, 40 (2): 125-131. https://doi.org/10.5038/1827-806X.40.2.5

Barabesi C., Galizzi A., Mastromei G., Rossi M., Tamburini E. \& Perito B., 2007 - Bacillus subtilis gene cluster involved in calcium carbonate biomineralization. Journal of Bacteriology, 189 (1): 228-235.

https://doi.org/10.1128/JB.01450-06

Barton H.A. \& Luiszer F., 2005 - Microbial metabolic structure in a sulfidic cave hot spring: Potential mechanisms of biospeleogenesis. Journal of Cave and Karst Studies, 67 (1): 28-38.

http://ww.caves.org/pub/journal/PDF/V67/v67n1Barton-Luiszer.pdf

Barton H.A. \& Northup D.E., 2007 - Geomicrobiology in cave environments: Past, current and future perspectives. Journal of Cave and Karst Studies, 69 (1): 163-178.

http://ww.caves.org/pub/journal/PDF/v69/cave-6901-163.pdf

Barton H.A., Taylor N.M., Kreate M.P., Springer A.C., Oehrle S.A. \& Bertog J.L., 2007 - The impact of host rock geochemistry on bacterial community structure in oligotrophic cave environments. International Journal of Speleology, 36 (2): 93-104.

https://doi.org/10.5038/1827-806X.36.2.5

Baskar S., Baskar R., Lee N. \& Theophilus P.K., 2009 - Speleothems from Mawsmai and Krem Phyllut caves, Meghalaya, India: some evidences on biogenic activities. Environmental Geology, 57 (5): 1169-1186. https://doi.org/10.1007/s00254-008-1413-y

Bautista-Hernández D., Ramírez-Burgos L., DuranPáramo E. \& Fernández-Linares L., 2012 - Zinc and lead biosorption by Delftia tsuruhatensis: A bacterial strain Resistant to metals isolated from mine tailings. Journal of Water Resource and Protection, 4 (4): 207-216. https://doi.org/10.4236/jwarp.2012.44023

Benson C.A., Bizzoco R.W., Lipson D.A. \& Kelley S.T., 2011 - Microbial diversity in nonsulfur, sulfur and iron 
geothermal steam vents. FEMS Microbiology Ecology, 76 (1): 74-88.

https://doi.org/10.1111/j.1574-6941.2011.01047.x

Briceño-Prieto S., 2011 - Caracterización geoquimica de los megacristales de yeso de Naica, Chihuahua y su relación con los procesos de interacción aguaroca. Unpublished Master Thesis, Geology Institute, Universidad Nacional Autónoma de México, 106 p.

Campbell J.W., Watson A., Watson C., Ball H. \& Pirkle R., 2011 - Escherichia coli, other coliform, and environmental chemoheterotrophic bacteria in isolated water pools from six caves in Northern Alabama and Northwestern Georgia. Journal of Cave and Karst Studies, 73 (2): 75-82.

https://doi.org/10.4311/jcks2009mb0131

Cleary D.F.R., Smalla K., Mendonca-Hagler L.C.S. \& Gomes N.C.M., 2012 - Assessment of variation in bacterial composition among microhabitats in a mangrove environment using DGGE fingerprints and barcoded pyrosequencing. PLoS One, 7 (1): e29380. https://doi.org/10.1371/journal.pone.0029380

Colwell F.S. \& D'Hondt S., 2013 - Nature and extent of the deep biosphere. Reviews in Mineralogy and Geochemistry, 75 (1): 547-574.

https://doi.org/10.2138/rmg.2013.75.17

Cuezva S., Fernandez-Cortes A., Porca E., Pasic L., Jurado V., Hernández-Marine M., Serrano-Ortiz P., Hermosin B., Cañaveras J.C., Sanchez-Moral S. \& Saiz-Jimenez C., 2012 - The biogeochemical role of Actinobacteria in Altamira Cave, Spain. FEMS Microbiology Ecology, 81 (1): 281-290.

https://doi.org/10.1111/j.1574-6941.2012.01391.x

Chelius M.K., Beresford G., Horton H., Quirk M., Selby G., Simpson R.T., Horrocks R. \& Moore J.C., 2009 Impacts of alterations of organic inputs on the bacterial community within the sediments of Wind Cave, South Dakota, USA. International Journal of Speleology, 38 (1-2): 1-10. https://doi.org/10.5038/1827-806X.38.1.1

Chen M.-Y., Tsay S.-S., Chen K.-Y., Shi Y.-C., Lin Y.-T. \& Lin G.-H., 2002 - Pseudoxanthomonas taiwanensis sp. nov., a novel thermophilic, $\mathrm{N}_{2} \mathrm{O}$-producing species isolated from hot springs. International Journal of Systematic and Evolutionary Microbiology, 52 (6): 2155-2161.

https://doi.org/10.1099/00207713-52-6-2155

Chou Y.-J., Sheu S.-Y., Sheu D.-S., Wang J.-T. \& Chen W.-M., 2006 - Schlegelella aquatica sp. nov., a novel thermophilic bacterium isolated from a hot spring. International Journal of Systematic and Evolutionary Microbiology, 56 (12): 2793-2797.

https://doi.org/10.1099/ijs.0.64446-0

da Costa A.C.A. \& Duta F.P., 2001 - Bioaccumulation of copper, zinc, cadmium and lead by Bacillus sp., Bacillus cereus, Bacillus sphaericus and Bacillus subtilis. Brazilian Journal of Microbiology, 32 (1): 1-5. https://doi.org/10.1590/S1517-83822001000100001

Diels L., Van Roy S., Taghavi S. \& Van Houdt R., 2009 From industrial sites to environmental applications with Cupriavidus metallidurans. Antonie Van Leeuwenhoek, 96 (2): 247-258. https://doi.org/10.1007/s10482-009-9361-4

Elbanna K., Lütke-Eversloh T., Van Trappen S., Mergaert J., Swings J. \& Steinbüchel A., 2003 Schlegelella thermodepolymerans gen. nov., sp. nov., a novel thermophilic bacterium that degrades poly(3-hydroxybutyrate-co-3-mercaptopropionate). International Journal of Systematic and Evolutionary Microbiology, 53 (4): 1165-1168.

https://doi.org/10.1099/ijs.0.02562-0
Engel A.S., 2010 - Microbial diversity of cave ecosystems. In: Barton L.L., Mandl M. \& Loy A. (Eds.), Geomicrobiology: Molecular and environmental perspective. Springer Science+Business Media B.V., p. 219-238.

https://doi.org/10.1007/978-90-481-9204-5 10

Epure L., Meleg I.N., Munteanu C.M., Roban R.D. \& Moldovan O.T., 2014 - Bacterial and fungal diversity of quaternary cave sediment deposits. Geomicrobiology Journal, 31 (2): 116-127. https://doi.org/10.1080/01490451.2013.815292

Forti P., Galli E. \& Rossi A., 2009 - Minerogenesis in the Naica Caves (Chihuahua, Mexico). Proceedings of the $15^{\text {th }}$ International Congress of Speleology, Kerville Texas, 1: 300-305.

Forti P. \& Sanna L., 2010 - The Naica Project - A multidisciplinary study of the largest gypsum crystals of the world. Episodes, 33 (1): 23-32.

Fry J.C., Webster G., Cragg B.A., Weightman A.J. \& Parkes R.J., 2006 - Analysis of DGGE profiles to explore the relationship between prokaryotic community composition and biogeochemical processes in deep subseafloor sediments from the Peru Margin. FEMS Microbiology Ecology, 58 (1): 86-98.

https://doi.org/10.1111/j.1574-6941.2006.00144.x

Garcia-Ruiz J.M., Villasuso R., Ayora C., Canals A. \& Otalora F., 2007 - Formation of natural gypsum megacrystals in Naica, Mexico. Geology, 35 (4): 327-330. https://doi.org/10.1130/G23393A.1

Garofalo P.S., Fricker M.B., Gunther D., Forti P., Mercuri A.M., Loreti M. \& Capaccioni B., 2010 - Climatic control on the growth of gigantic gypsum crystals within hypogenic caves (Naica mine, Mexico)? Earth and Planetary Science Letters, 289 (3-4): 560-569. https://doi.org/10.1016/j.eps1.2009.11.057

Govarthanan M., Lee K.-J., Cho M., Kim J.S., KamalaKannan S. \& Oh B.-T., 2013 - Significance of autochthonous Bacillus sp. KK1 on biomineralization of lead in mine tailings. Chemosphere, 90 (8): 2267-2272. https://doi.org/10.1016/j.chemosphere.2012.10.038

Griffin D.W., Gray M.A., Lyles M.B. \& Northup D.E., 2014 - The transport of nonindigenous microbes into caves by human visitations: A case study at Carlsbad Caverns National Park. Geomicrobiology Journal, 31: 175-185. https://doi.org/10.1080/01490451.2013.815294

Herzog Velikonja B., Tkavc R. \& Pašić L., 2014 - Diversity of cultivable bacteria involved in the formation of microbial colonies (cave silver) on the walls of a cave in Slovenia. International Journal of Speleology, 43 (1): 45-56. https://doi.org/10.5038/1827-806X.43.1.5

Ikner L.A., Toomey R.S., Nolan G., Neilson J.W., Pryor B.M. \& Maier R.M., 2007 - Culturable microbial diversity and the impact of tourism in Kartchner Caverns, Arizona. Microbial Ecology, 53 (1): 30-42. https://doi.org/10.1007/s00248-006-9135-8

Jimenez L., 1990 - Molecular analysis of deep-subsurface bacteria. Applied and Environmental Microbiology, 56 (7): 2108-2113.

http://aem.asm.org/content/56/7/2108.short

Jones D.S., Lyon E.H. \& Macalady J.L., 2008 Geomicrobiology of biovermiculations from the Frasassi Cave System, Italy. Journal of Cave and Karst Studies, 70 (2): 78-93.

http://ww.caves.org/pub/journal/PDF/v70/cave-70$\underline{02-78 . p d f}$

Kallmeyer J. \& Wagner D., 2014 - Microbial life of the deep biosphere. Walter de Gruyter GmbH, Berlin, 325 p. https://doi.org/10.1515/9783110300130

Kumaresan D., Hillebrand-Voiculescu A.M., Wischer D., Stephenson J., Chen Y. \& Murrell J.C., 2015 - 
Microbial life in unusual cave ecosystems sustained by chemosynthetic primary production. In: Summers Engel A. (Ed.), Microbial life of cave systems. Life in extreme environments. Walter de Gruyter GmbH, Berlin, p. 215225. https://doi.org/10.1515/9783110339888-012

Lavoie K.H. \& Northup D.E., 2005 - Bacteria as indicators of human impact in caves. Proceedings of the $7^{\text {th }}$ National Cave and Karst Management Symposium. NICKMS Steering Committee, Albany, NY, p. 40-47.

Leuko S., Koskinen K., Sanna L., D’Angeli I.M., De Waele J., Marcia P., Moissl-Eichinger C. \& Rettberg P., 2017 - The influence of human exploration on the microbial community structure and ammonia oxidizing potential of the Su Bentu limestone cave in Sardinia, Italy. PLoS One, 12 (7): e0180700.

https://doi.org/10.1371/journal.pone.0180700

López-Moreno A., Sepúlveda-Sánchez J.D., Mercedes Alonso Guzmán E.M. \& Le Borgne S., 2014 - Calcium carbonate precipitation by heterotrophic bacteria isolated from biofilms formed on deteriorated ignimbrite stones: influence of calcium on EPS production and biofilm formation by these isolates. Biofouling, 30 (5): 547-560.

https://doi.org/10.1080/08927014.2014.888715

Lozano R.P. \& Rossi C., 2012 - Exceptional preservation of Mn-oxidizing microbes in cave stromatolites (El Soplao, Spain). Sedimentary Geology, 255: 42-55. https://doi.org/10.1016/j.sedgeo.2012.02.003

Marín Herrera B.R., Vogel González F. \& Echegoyén Guzmán R., 2006 - Las megaselenitas del distrito minero de Naica, Chihuahua, una ocurrencia mineralógica anómala. Boletín de Mineralogía, 17: 139-148.

Moser D.P., Onstott T.C., Fredrickson J.K., Brockman F.J., Balkwill D.L., Drake G.R., Pfiffner S.M., White D.C., Takai K., Pratt L.M., Fong J., Lollar B.S., Slater G., Phelps T.J., Spoelstra N., Deflaun M., Southam G., Welty A.T., Baker B.J. \& Hoek J., 2003 - Temporal shifts in the geochemistry and microbial community structure of an ultradeep mine borehole following isolation. Geomicrobiology Journal, 20 (6): 517-548. https://doi.org/10.1080/713851170

Mulec J., 2008 - Microbes in hypogeon: Examples from Slovenian Karst caves. Acta Carsologica, 37 (1): 153-160. https://doi.org/10.3986/ac.v37i1.167

Muyzer G., Brinkoff T., Nübel U., Santegoeds C., Schäfer H. \& Wawer C., 2004 - Denaturing gradient gel electrophoresis (DGGE) in microbial ecology. In: Kowalchuk G.A., de Bruijn F.J., Head I.M., Van der Zijpp A.J. \& van Elsas J.D. (Eds.), Molecular microbial ecology manual. Springer Science+Business Media B.V., p. 743-770.

Muyzer G., Dewaal E.C. \& Uitterlinden A.G., 1993 Profiling of complex microbial populations by denaturing gradient gel electrophoresis analysis of polymerase chain reaction-amplified genes coding for $16 S$ rRNA. Applied and Environmental Microbiology, 59 (3): 695700. http://aem.asm.org/content/59/3/695.short

Nakatsu C.H., Torsvik V. \& Øvreas L., 2000 - Soil community analysis using DGGE of $16 \mathrm{~S}$ rDNA polymerase chain reaction products. Soil Science Society of America Journal, 64 (4): 1382-1388. https://doi.org/10.2136/sssaj2000.6441382x

North N.N., Dollhopf S.L., Petrie L., Istok J.D., Balkwill D.L. \& Kostka J.E., 2004 - Change in bacterial community structure during in situ biostimulation of subsurface sediment cocontaminated with uranium and nitrate. Applied and Environmental Microbiology, 70 (8): 4911-4920.

https://doi.org/10.1128/AEM.70.8.4911-4920.2004
Northup D.E., Barns S.M., Yu L.E., Spilde M.N., Schelble R.T., Dano K.E., Crossey L.J., Connolly C.A., Boston P.J., Natvig D.O. \& Dahm C.N., 2003 - Diverse microbial communities inhabiting ferromanganese deposits in Lechuguilla and Spider Caves. Environmental Microbiology, 5 (11): 1071-1086. https://doi.org/10.1046/j.1462-2920.2003.00500.x

Onstott T.C., Moser D.P., Pfiffner S.M., Fredrickson J.K., Brockman F.J., Phelps T.J., White D.C., Peacock A., Balkwill D., Hoover R., Krumholz L.R., Borscik M., Kieft T.L. \& Wilson R., 2003 - Indigenous and contaminant microbes in ultradeep mines. Environmental Microbiology, 5 (11): 1168-1191.

https://doi.org/10.1046/j.1462-2920.2003.00512.x

Parkes R.J., Linnane C.D., Webster G., Sass H., Weightman A.J., Hornibrook E.R.C. \& Horsfield B., 2011 - Prokaryotes stimulate mineral $\mathrm{H}_{2}$ formation for the deep biosphere and subsequent thermogenic activity. Geology, 39 (3): 219-222.

https://doi.org/10.1130/G31598.1

Parkes R.J., Webster G., Cragg B.A., Weightman A.J., Newberry C.J., Ferdelman T.G., Kallmeyer J., Jorgensen B.B., Aiello I.W. \& Fry J.C., 2005 - Deep sub-seafloor prokaryotes stimulated at interfaces over geological time. Nature, 436: 390-394.

https://doi.org/10.1038/nature03796

Portillo M.C. \& Gonzalez J.M., 2011 - Moonmilk deposits originate from specific bacterial communities in Altamira Cave (Spain). Microbial Ecology, 61 (1): 182-189. https://doi.org/10.1007/s00248-010-9731-5

Ragon M., Van Driessche A.E.S., Garcia-Ruiz J., Moreira D. \& Lopez-Garcia P., 2013 - Microbial diversity in the deep-subsurface hydrothermal aquifer feeding the giant gypsum crystal-bearing Naica Mine, Mexico. Frontiers in Microbiology, 4 (37): 1-12.

https://doi.org/10.3389/fmicb.2013.00037

Rasband W.S., 2012 - Image J. U. S. National Institutes of Health, Bethesda, Maryland, USA.

http://imagej.nih.gov/ij/

Rastogi G., Stetler L.D., Peyton B.M. \& Sani R.K., 2009 - Molecular analysis of prokaryotic diversity in the deep subsurface of the former homestake Gold Mine, South Dakota, USA. Journal of Microbiology, 47 (4): 371-384. https://doi.org/10.1007/s12275-008-0249-1

Reith F., Fairbrother L., Nolze G., Wilhelmi O., Clode P.L., Gregg A., Parsons J.E., Wakelin S.A., Pring A., Hough R., Southam G. \& Brugger J., 2010 - Nanoparticle factories: Biofilms hold the key to gold dispersion and nugget formation. Geology, 38 (9): 843-846.

https://doi.org/10.1130/G31052.1

Rivadeneyra M.A., Delgado G., Ramos-Cormenzana A. \& Delgado R., 1998 - Biomineralization of carbonates by Halomonas eurihalina in solid and liquid media with different salinities: crystal formation sequence. Research in Microbiology, 149 (4): 277-287.

https://doi.org/10.1016/S0923-2508(98)80303-3

Rusznyák A., Akob D.M., Nietzsche S., Eusterhues K., Totche K.U., Neu T.R., Frosch T., Popp J., Keiner R., Geletneky J., Katszchmann L., Schulze E.D. \& Küsel K., 2012 - Calcite biomineralization by bacterial isolates from the recently discovered pristine karstic Herrenberg Cave. Applied and Environmental Microbiology, 78 (4): 1157-1167.

https://doi.org/10.1128/AEM.06568-11

Spear J.R., Barton H.A., Robertson C.E., Francis C.A. \& Pace N.R., 2007 - Microbial community biofabrics in a geothermal mine adit. Applied and Environmental Microbiology, 73 (19): 6172-6180. https://doi.org/10.1128/AEM.00393-07 
Spilde M.N., Northup D.E., Boston P.J., Schelble R.T., Dano K.E., Crossey L.J. \& Dahm C.N., 2005 Geomicrobiology of cave ferromanganese deposits: A field and laboratory investigation. Geomicrobiology Journal, 22 (3-4): 99-116. https://doi.org/10.1080/01490450590945889

Sujith P.P. \& Bharathi P.A.L., 2011 - Manganese oxidation by bacteria: Biogeochemical aspects. In: Müller W.E.G. (Ed.), Molecular biomineralization: Aquatic organisms forming extraordinary materials. Springer, Berlin, Heidelberg, p. 49-76.

https://doi.org/10.1007/978-3-642-21230-7 3

Tomova I., Lazarkevich I., Tomova A., Kambourova M. \& Vasileva-Tonkova E., 2013 - Diversity and biosynthetic potential of culturable aerobic heterotrophic bacteria isolated from Magura Cave, Bulgaria. International Journal of Speleology, 42 (1): 65-76. https://doi.org/10.5038/1827-806X.42.1.8

Tuhela L., Smith S.A. \& Tuovinen O.H., 1993 Microbiological analysis of iron-related biofouling in water wells and a flow-cell apparatus for field and laboratory investigations. Ground Water, 31 (6): 982-988. https://doi.org/10.1111/j.1745-6584.1993.tb00872.x

Ubalde M.C., Brana V., Sueiro F., Morel M.A., MartinezRosales C., Marquez C. \& Castro-Sowinski S., 2012 - The versatility of Delftia $s p$. isolates as tools for bioremediation and biofertilization technologies. Current Microbiology, 64 (6): 597-603. https://doi.org/10.1007/s00284-012-0108-5

Webster G., Parkes R.J., Cragg B.A., Newberry C.J., Weightman A.J. \& Fry J.C., 2006 - Prokaryotic community composition and biogeochemical processes in deep subseafloor sediments from the Peru Margin. FEMS Microbiology Ecology, 58 (1): 65-85.

https://doi.org/10.1111/j.1574-6941.2006.00147.x

Wei D.-Q., Yu T.-T., Yao J.-C., Zhou E.-M., Song Z.Q., Yin Y.-R., Ming H., Tang S.-K. \& Li W.-J., 2012 - Lysobacter thermophilus sp. nov., isolated from a geothermal soil sample in Tengchong, south-west China. Antonie Van Leeuwenhoek, 102 (4): 643-651. https://doi.org/10.1007/s10482-012-9761-8

Yakimov M.M., Timmis K.N., Wray V. \& Fredrickson H.L., 1995 - Characterization of a new lipopeptide surfactant produced by thermotolerant and halotolerant subsurface Bacillus licheniformis BAS50. Applied and Environmental Microbiology, 61 (5): 1706-1713. http://aem.asm.org/content/61/5/1706.short

Zastrow P. \& Straube G., 1991 - Leaching of copper ores by chemoorganotrophic microbes Applied Microbiology and Biotechnology, 35 (5): 696-698.

https://doi.org/10.1007/BF00169640

Zhang H.B., Shi W., Yang M.X., Sha T. \& Zhao Z.W., 2007a - Bacterial diversity at different depths in lead-zinc mine tailings as revealed by 16S rRNA gene libraries. Journal of Microbiology, 45 (6): 479-484.

Zhang H.B., Yang M.X., Shi W., Zheng Y., Sha T. \& Zhao Z.W., 2007b - Bacterial diversity in mine tailings compared by cultivation and cultivation-independent methods and their resistance to lead and cadmium. Microbial Ecology, 54 (4): 705-712. https://doi.org/10.1007/s00248-007-9229-y 